\title{
New Cladosporium Species from Normal and Galled Flowers of Lamiaceae
}

\author{
Beata Zimowska ${ }^{1}$, Andrea Becchimanzi ${ }^{2}$ (D), Ewa Dorota Krol ${ }^{1}$, Agnieszka Furmanczyk ${ }^{1}$, Konstanze Bensch ${ }^{3}$ \\ and Rosario Nicoletti $2,4, *$ (D)
}

1 Department of Plant Protection, University of Life Sciences, 20-068 Lublin, Poland; beata.zimowska@up.lublin.pl (B.Z.); ewa.krol@up.lublin.pl (E.D.K.); agnieszka.furmanczyk@up.lublin.pl (A.F.)

2 Department of Agricultural Sciences, University of Naples Federico II, 80055 Portici, Italy; andrea.becchimanzi@unina.it

3 Westerdijk Fungal Biodiversity Institute, Uppsalalaan 8, 3584 CT Utrecht, The Netherlands; k.bensch@wi.knaw.nl

4 Council for Agricultural Research and Economics, Research Centre for Olive, Fruit and Citrus Crops, 81100 Caserta, Italy

* Correspondence: rosario.nicoletti@crea.gov.it

Citation: Zimowska, B.

Becchimanzi, A.; Krol, E.D.;

Furmanczyk, A.; Bensch, K.; Nicoletti,

R. New Cladosporium Species from

Normal and Galled Flowers of

Lamiaceae. Pathogens 2021, 10, 369.

https://doi.org/10.3390/

pathogens 10030369

Academic Editor: Giovanni Bubici

Received: 26 February 2021

Accepted: 17 March 2021

Published: 19 March 2021

Publisher's Note: MDPI stays neutral with regard to jurisdictional claims in published maps and institutional affiliations.

Copyright: (c) 2021 by the authors. Licensee MDPI, Basel, Switzerland. This article is an open access article distributed under the terms and conditions of the Creative Commons Attribution (CC BY) license (https:// creativecommons.org/licenses/by/ $4.0 /)$

\begin{abstract}
A series of isolates of Cladosporium spp. were recovered in the course of a cooperative study on galls formed by midges of the genus Asphondylia (Diptera, Cecidomyidae) on several species of Lamiaceae. The finding of these fungi in both normal and galled flowers was taken as an indication that they do not have a definite relationship with the midges. Moreover, identification based on DNA sequencing showed that these isolates are taxonomically heterogeneous and belong to several species which are classified in two different species complexes. Two new species, Cladosporium polonicum and Cladosporium neapolitanum, were characterized within the Cladosporium cladosporioides species complex based on strains from Poland and Italy, respectively. Evidence concerning the possible existence of additional taxa within the collective species C. cladosporioides and C. pseudocladosporioides is discussed.
\end{abstract}

Keywords: Asphondylia flower galls; Cladosporium cladosporioides species complex; Cladosporium neapolitanum; Cladosporium polonicum; Lamiaceae

\section{Introduction}

Fungi belonging to the genus Cladosporium (Dothideomycetes, Cladosporiaceae) are ubiquitous and reported to be able to colonize a huge diversity of substrates in any natural or anthropized environment on earth [1]. They are well known as plant disease agents [1-5], but also reported as pathogens of animals [6] and humans [7-9], and are considered among the most widespread fungi in buildings and indoor environments [10]. Other species are endophytic or have been reported from soil, dung or leaf litter [11-14]. Recent investigations have shown that pathogenic strains usually belong to species mostly known as saprophytes, underlining the importance of an accurate assessment of the phylogenetic relationships for the identification of specialized lineages and possible cryptic species $[1,7,8,10]$. In fact, classification based on morphology has proved to be problematic due to the infrequency of the perfect stage and the absence of outstanding differences in the conidial structures, so that culturing and microscope observations only allowed a partial separation of taxa possibly representing collective species. Therefore, widespread species, such as C. cladosporioides, C. herbarum, and C. sphaerospermum, are now regarded as species complexes (s.c.), disclosing a broader variation as and when the characterization of new strains proceeds from new ecological contexts and geographic areas [3]. Indeed, the easier access to DNA sequencing and online databases is ongoingly supporting the distinction of novel species, to such an extent that within the C. cladosporioides s.c. their number has currently raised up to 67 (Table 1 ). 
Table 1. List of Cladosporium strains from accepted taxa and their corresponding DNA sequences which have been used in the phylogenetic analyses.

\begin{tabular}{|c|c|c|c|c|c|c|}
\hline Species & Code & Host & Country & ITS & TEF1 & $\mathrm{ACT}$ \\
\hline C. acalyphae & CBS 125982 & Acalypha australis & South Korea & HM147994 & HM148235 & HM148481 \\
\hline C. alboflavescens & CBS 140690 & $\begin{array}{l}\text { bronchoalveolar } \\
\text { lavage fluid }\end{array}$ & United States & LN834420 & LN834516 & LN834604 \\
\hline C. angulosum & СРC 22271 & indoor air & United States & MF472918 & MF473345 & MF473768 \\
\hline C. angulosum & CBS 140692 & $\begin{array}{l}\text { bronchoalveolar } \\
\text { lavage fluid }\end{array}$ & United States & LN834425 & LN834521 & LN834609 \\
\hline C. angustisporum & CBS 125983 & Alloxylon wickhamii & Australia & HM147995 & HM148236 & HM148482 \\
\hline C. angustisporum & DTO-127-E6 & air in bakery & United States & KP701935 & KP701812 & KP702057 \\
\hline C. angustiterminale & CBS 140480 & Banksia grandis & Australia & KT600379 & KT600476 & KT600575 \\
\hline C. anthropophilum & CBS 117483 & - & United States & HM148007 & HM148248 & HM148494 \\
\hline C. anthropophilum & СРC 22393 & indoor air & United States & MF472922 & MF473349 & MF473772 \\
\hline C. arenosum & CHFC-EA 566 & marine sediment & Antarctica & MN879328 & MN890011 & MN890008 \\
\hline C. asperulatum & CBS 126340 & Protea susannae & Portugal & HM147998 & HM148239 & HM148485 \\
\hline C. asperulatum & CBS 126339 & leaf litter & India & HM147997 & HM148238 & HM148484 \\
\hline C. australiense & DTO-255-F3 & bathroom & Netherlands & KP701978 & KP701855 & KP702100 \\
\hline C. australiense & CBS 125984 & Eucalyptus moluccana & Australia & HM147999 & HM148240 & HM148486 \\
\hline C. austroafricanum & CBS 140481 & leaf litter & South Africa & KT600381 & KT600478 & KT600577 \\
\hline C. chalastosporoides & CBS 125985 & $\begin{array}{c}\text { Teratosphaeria } \\
\text { proteae-arboreae on } \\
\text { Protea arborea }\end{array}$ & South Africa & HM148001 & HM148242 & HM148488 \\
\hline C. chasmanthicola & CBS 142612 & Chasmanthe aethiopica & South Africa & KY646221 & KY646227 & KY646224 \\
\hline C. chubutense & CBS 124457 & Pinus ponderosa & Argentina & FJ936158 & FJ936161 & FJ936165 \\
\hline C. cladosporioides & CBS 113739 & crested wheat grass & United States & HM148005 & HM148246 & HM148492 \\
\hline C. cladosporioides & CBS 145.35 & Pisum sativum & Germany & HM148013 & HM148254 & HM148500 \\
\hline C. cladosporioides & CBS 101367 & soil & Brazil & HM148002 & HM148243 & HM148489 \\
\hline C. cladosporioides & CBS 112388 & indoor air & Germany & HM148003 & HM148244 & HM148490 \\
\hline C. cladosporioides & CPC 15615 & wild tree & Mexico & KT600386 & KT600483 & KT600581 \\
\hline C. cladosporioides & CPC 22367 & indoor air & United States & MF472941 & MF473368 & MF473791 \\
\hline C. cladosporioides & СРC 14271 & unidentified tree & France & HM148045 & HM148286 & HM148532 \\
\hline C. cladosporioides & СРC 15626 & wild plant & Mexico & KT600387 & KT600484 & KT600582 \\
\hline C. colocasiae & CBS 386.64 & Colocasia esculenta & Taiwan & HM148067 & HM148310 & HM148555 \\
\hline C. colocasiae & CBS 119542 & Colocasia esculenta & Japan & HM148066 & HM148309 & HM148554 \\
\hline C. colombiae & CBS 274.80B & Cortaderia sp. & Colombia & FJ936159 & FJ936163 & FJ936166 \\
\hline C. crousii & CBS 140686 & $\begin{array}{l}\text { bronchoalveolar } \\
\text { lavage fluid }\end{array}$ & United States & LN834431 & LN834527 & LN834615 \\
\hline C. cucumerinum & CBS 174.62 & painted floor & United States & HM148076 & HM148320 & HM148565 \\
\hline C. cucumerinum & CBS 174.54 & Cucumis sativus & Netherlands & HM148075 & HM148319 & HM148564 \\
\hline C. delicatulum & CBS 126342 & indoor air & Denmark & HM148079 & HM148323 & HM148568 \\
\hline C. delicatulum & CBS 126344 & Tilia cordata & Germany & HM148081 & HM148325 & HM148570 \\
\hline C. europaeum & CBS 134914 & building material & Denmark & HM148056 & HM148298 & HM148543 \\
\hline C. europaeum & СРС 14238 & $\begin{array}{c}\text { fruit of } \\
\text { Sambucus nigra }\end{array}$ & Netherlands & HM148055 & HM148297 & HM148542 \\
\hline C. exasperatum & CBS 125986 & Eucalyptus tintinnans & Australia & HM148090 & HM148334 & HM148579 \\
\hline C. exile & CBS 125987 & $\begin{array}{l}\text { Phyllactinia guttata on } \\
\text { leaf of Corylus sp. }\end{array}$ & United States & HM148091 & HM148335 & HM148580 \\
\hline C. flabelliforme & CBS 126345 & Melaleuca cajuputi & Australia & HM148092 & HM148336 & HM148581 \\
\hline C. flavovirens & CBS 140462 & toe nail & United States & LN834440 & LN834536 & LN834624 \\
\hline C. funiculosum & CBS 122129 & Vigna umbellata & Japan & HM148094 & HM148338 & HM148583 \\
\hline
\end{tabular}


Table 1. Cont

\begin{tabular}{|c|c|c|c|c|c|c|}
\hline Species & Code & Host & Country & ITS & TEF1 & ACT \\
\hline C. funiculosum & CBS 122128 & Ficus carica & Japan & HM148093 & HM148337 & HM148582 \\
\hline C. gamsianum & CBS 125989 & Strelitzia sp. & South Africa & HM148095 & HM148339 & HM148584 \\
\hline C. gamsianum & СРC 15617 & seeds of Glycine max & Mexico & KT600392 & KT600489 & KT600587 \\
\hline C. globisporum & CBS 812.96 & meat stamp & Sweden & HM148096 & HM148340 & HM148585 \\
\hline C. globisporum & DTO-220-D4 & indoor environment & Netherlands & KP701967 & KP701844 & KP702089 \\
\hline C. grevilleae & CBS 114271 & leaf of Grevillea sp. & Australia & JF770450 & JF770472 & JF770473 \\
\hline C. hillianum & CBS 125988 & leaf of Typha orientalis & New Zealand & HM148097 & HM148341 & HM148586 \\
\hline C. hillianum & СРC 15458 & leaf of Typha orientalis & New Zealand & HM148098 & HM148342 & HM148587 \\
\hline C. inversicolor & CBS 401.80 & Triticum aestivum & Netherlands & HM148101 & HM148345 & HM148590 \\
\hline C. inversicolor & DTO-108-F8 & indoor environment & France & KP701908 & KP701785 & KP702031 \\
\hline C. ipereniae & CBS 140483 & Puya sp. & Chile & KT600394 & KT600491 & KT600589 \\
\hline C. ipereniae & СРC 16855 & Arctostaphylos pallida & United States & KT600395 & KT600492 & KT600590 \\
\hline C. iranicum & CBS 126346 & leaf of Citrus sinensis & Iran & HM148110 & HM148354 & HM148599 \\
\hline C. kenpeggii & CBS 142613 & leaf of Passiflora edulis & Australia & KY646222 & KY646228 & KY646225 \\
\hline C. licheniphilum & CBS 125990 & Physcia sp. & Germany & HM148111 & HM148355 & HM148600 \\
\hline C. longicatenatum & CBS 140485 & unknown plant & Australia & KT600403 & KT600500 & KT600598 \\
\hline C. lycoperdinum & CBS 274.80C & Puya sp. & Colombia & HM148114 & HM148358 & HM148603 \\
\hline C. lycoperdinum & CBS 126347 & $\begin{array}{l}\text { gall of Apiosporina } \\
\text { morbosa on Prunus sp. }\end{array}$ & Canada & HM148112 & HM148601 & HM148601 \\
\hline C. montecillanum & CBS 140486 & pine needles & Mexico & KT600406 & KT600504 & KT600602 \\
\hline C. montecillanum & CPC 15605 & Taraxacum sp. & Mexico & KT600407 & KT600505 & KT600603 \\
\hline C. myrtacaearum & CBS 126350 & Corymbia foelscheana & Australia & HM148117 & HM148361 & HM148606 \\
\hline C. myrtacaearum & CBS 126349 & Eucalyptus placita & Australia & MH863925 & HM148360 & HM148605 \\
\hline C. needhamense & CBS 143359 & indoor air sample & United States & MF473142 & MF473570 & MF473991 \\
\hline C. neerlandicum & CBS 143360 & archive dust & Netherlands & KP701887 & KP701764 & KP702010 \\
\hline C. neopsychrotolerans & CGMCC3.18031 & $\begin{array}{c}\text { rhizosphere of } \\
\text { Saussurea involucrata }\end{array}$ & China & KX938383 & KX938400 & KX938366 \\
\hline C. neopsychrotolerans & CGMCC3.18032 & $\begin{array}{c}\text { rhizosphere of } \\
\text { Saussurea involucrata }\end{array}$ & China & KX938384 & KX938401 & KX938367 \\
\hline C. oxysporum & CBS 125991 & soil & China & HM148118 & HM148362 & HM148607 \\
\hline C. oxysporum & CBS 126351 & indoor air & Venezuela & HM148119 & HM148363 & HM148608 \\
\hline C. paracladosporioides & CBS 171.54 & - & - & HM148120 & HM148364 & HM148609 \\
\hline C. parapenidielloides & CBS 140487 & Eucalyptus sp. & Australia & KT600410 & KT600508 & KT600606 \\
\hline C. perangustum & CBS 125996 & Cussonia sp. & South Africa & HM148121 & HM148365 & HM148610 \\
\hline C. perangustum & CBS 126365 & $\begin{array}{l}\text { Phyllactinia guttata on } \\
\text { leaf of Corylus sp. }\end{array}$ & United States & MH863940 & HM148367 & HM148612 \\
\hline C. phaenocomae & CBS 128769 & Phaenocoma prolifera & South Africa & JF499837 & JF499875 & JF499881 \\
\hline C. phaenocomae & СРC 18221 & Phaenocoma prolifera & South Africa & JF499838 & JF499876 & JF499882 \\
\hline C. phyllactiniicola & CBS 126354 & $\begin{array}{l}\text { Phyllactinia guttata on } \\
\text { leaf of Corylus sp. }\end{array}$ & United States & MH863930 & HM148396 & HM148641 \\
\hline C. phyllactiniicola & CBS 126355 & $\begin{array}{l}\text { Phyllactinia guttata on } \\
\text { leaf of Corylus sp. }\end{array}$ & United States & HM148153 & HM148397 & HM148642 \\
\hline C. phyllophilum & CBS 125992 & $\begin{array}{l}\text { Taphrina sp. on } \\
\text { Prunus cerasus }\end{array}$ & Germany & HM148154 & HM148398 & HM148643 \\
\hline C. phyllophilum & СРC 13873 & $\begin{array}{c}\text { Teratosphaeria } \\
\text { proteae-arboreae on } \\
\text { Protea arborea }\end{array}$ & South Africa & HM148155 & HM148399 & HM148644 \\
\hline C. pini-ponderosae & CBS 124456 & Pinus ponderosa & Argentina & FJ936160 & FJ936164 & FJ936167 \\
\hline C. pseudochalastosporoides & CBS 140490 & pine needles & Mexico & KT600415 & KT600513 & KT600611 \\
\hline
\end{tabular}


Table 1. Cont.

\begin{tabular}{|c|c|c|c|c|c|c|}
\hline Species & Code & Host & Country & ITS & TEF1 & ACT \\
\hline C. pseudocladosporioides & CBS 125993 & air & Netherlands & HM148158 & HM148402 & HM148647 \\
\hline C. pseudocladosporioides & CBS 117153 & leaf of Paeonia sp. & Germany & HM148157 & HM148401 & HM148646 \\
\hline C. ramotenellum & CPC 14300 & building material & Denmark & KT600438 & KT600537 & KT600635 \\
\hline C. rectoides & CBS 125994 & Vitis flexuosa & South Korea & HM148193 & HM148438 & HM148683 \\
\hline C. rectoides & CBS 126357 & Plectranthus sp. & South Korea & MH863933 & HM148439 & HM148684 \\
\hline C. rugulovarians & CBS 140495 & unidentified Poaceae & Brazil & KT600459 & KT600558 & KT600656 \\
\hline C. scabrellum & CBS 126358 & Ruscus hypoglossum & Slovenia & HM148195 & HM148440 & HM148685 \\
\hline C. silenes & CBS 109082 & Silene uniflora & $\begin{array}{l}\text { United } \\
\text { Kingdom }\end{array}$ & EF679354 & EF679429 & EF679506 \\
\hline C. silenes & $\begin{array}{l}\text { MFLUCC } \\
17-0195\end{array}$ & Vitis vinifera & China & MG938717 & MG938830 & MG938682 \\
\hline C. sinuatum & CGMCC3.18096 & soil & China & KX938385 & KX938402 & KX938368 \\
\hline C. sinuatum & CGMCC3.18097 & soil & China & KX938386 & KX938403 & KX938369 \\
\hline Cladosporium sp. & $\begin{array}{l}\text { UTHSC } \\
\text { DI-13-227 }\end{array}$ & human sputum & United States & LN834422 & LN834518 & LN834606 \\
\hline Cladosporium sp. & $\begin{array}{c}\text { UTHSC } \\
\text { DI-13-245 }\end{array}$ & toe & United States & LN834429 & LN834525 & LN834613 \\
\hline Cladosporium sp. & $\begin{array}{c}\text { UTHSC } \\
\text { DI-13-265 }\end{array}$ & $\begin{array}{c}\text { bronchoalveolar } \\
\text { lavage fluid }\end{array}$ & United States & LN834435 & LN834531 & LN834619 \\
\hline Cladosporium sp. & $\begin{array}{l}\text { UTHSC } \\
\text { DI-13-218 }\end{array}$ & $\begin{array}{l}\text { bronchoalveolar } \\
\text { lavage fluid }\end{array}$ & United States & LN834418 & LN834514 & LN834602 \\
\hline Cladosporium sp. & $\begin{array}{c}\text { UTHSC } \\
\text { DI-13-210 }\end{array}$ & human skin & United States & LN834414 & LN834510 & LN834598 \\
\hline C. subuliforme & CBS 126500 & Chamaedorea metallica & Thailand & HM148196 & HM148441 & HM148686 \\
\hline C. subuliforme & DTO-130-H8 & indoor environment & Thailand & KP701938 & KP701815 & KP702060 \\
\hline C. tenuissimum & XCSY3 & Coriandrum sativum & China & MG873079 & MT154184 & MT154174 \\
\hline C. tenuissimum & CBS 125995 & Lagerstoemia sp. & United States & HM148197 & HM148442 & HM148687 \\
\hline C. tianshanense & CGMCC3.18033 & $\begin{array}{c}\text { rhizosphere of } \\
\text { Saussurea involucrata }\end{array}$ & China & KX938381 & KX938398 & KX938364 \\
\hline C. tianshanense & CGMCC3.18034 & $\begin{array}{c}\text { rhizosphere of } \\
\text { Saussurea involucrata }\end{array}$ & China & KX938382 & KX938399 & KX938365 \\
\hline C. uredinicola & СРC 5390 & $\begin{array}{l}\text { Cronartium fusiforme } \\
\text { on Quercus nigra }\end{array}$ & United States & AY251071 & HM148467 & HM148712 \\
\hline C. uwebraunianum & CBS 143365 & indoor air & Netherlands & MF473306 & MF473729 & MF474156 \\
\hline C. uwebraunianum & DTO-305-H9 & house dust & New Zealand & MF473307 & MF473730 & MF474157 \\
\hline C. varians & CBS 126361 & leaf debris & India & MH863937 & HM148469 & HM148714 \\
\hline C. varians & CBS 126362 & Catalpa bungei & Russia & HM148224 & HM148470 & HM148715 \\
\hline C. verrucocladosporioides & CBS 126363 & Rhus chinensis & South Korea & HM148226 & HM148472 & HM148717 \\
\hline C. vicinum & CBS 143366 & indoor air & United States & MF473311 & MF473734 & MF474161 \\
\hline C. vicinum & CBS 306.84 & $\begin{array}{l}\text { uredospore of } \\
\text { Puccinia allii }\end{array}$ & $\begin{array}{l}\text { United } \\
\text { Kingdom }\end{array}$ & HM148057 & HM148299 & HM148544 \\
\hline C. vignae & CBS 121.25 & Vigna unguiculata & United States & HM148227 & HM148473 & HM148718 \\
\hline C. welwitschiicola & СРС 18648 & Welwitschia mirabilis & Namibia & KY646223 & KY646229 & KY646226 \\
\hline C. westerdijkiae & СРC 10150 & Fatoua villosa & South Korea & HM148062 & HM148304 & HM148549 \\
\hline C. westerdijkiae & СРC 14284 & Triticum sp. & Germany & HM148065 & HM148307 & HM148552 \\
\hline C. xanthocromaticum & CBS 126364 & $\begin{array}{l}\text { Erythrophleum } \\
\text { chlorostachys }\end{array}$ & Australia & HM148122 & HM148366 & HM148611 \\
\hline C. xanthocromaticum & СРС 22239 & indoor air & United States & MF473316 & MF473739 & MF474166 \\
\hline C. xylophilum & CBS 125997 & $\begin{array}{l}\text { dead wood of } \\
\text { Picea abies }\end{array}$ & Russia & HM148230 & HM148476 & HM148721 \\
\hline C. xylophilum & CBS 113749 & Prunus avium & United States & HM148228 & HM148474 & HM148719 \\
\hline
\end{tabular}


One of the most fruitful investigational fields on the occurrence of Cladosporium species is represented by the ecological interactions with other organisms. Particularly, many studies have evidenced the ability of these fungi to exert antagonistic effects against pests and pathogens of crops, which is also supported by their widespread association with plants as epiphytes or endophytes $[15,16]$. However, in other cases it has not been clearly established whether the finding of Cladosporium is related to a definite symbiotic interaction or to a merely saprophytic condition. One of these cases is represented by the association with midges belonging to the Asphondyliinae (Diptera, Cecidomyidae), which on many plant species induce the formation of galls where larvae develop by feeding on a mycelial mat lining the gall walls. The fungal counterpart was identified as Cladosporium sp. in early investigations on these peculiar symbiotic associations $[17,18]$. Later on, this role was questioned, although occurrence of Cladosporium in galls was confirmed in recent reports from several plants and countries worldwide [19-21]. Moreover, the finding of Cladosporium conidia in mycangia and on the body surface of egg-laying midges could possibly support the conjecture that the insect may actively spread the fungus during oviposition [21,22].

In the course of a cooperative investigational activity on the fungal associates developing in galls produced by midges of the genus Asphondylia in flowers of several species of Lamiaceae [23,24], strains of Cladosporium were frequently recovered during the isolation attempts. However, unlike Botryosphaeria dothidea which was only isolated from galls [25], Cladosporium isolates were also obtained from the inner parts of normal flowers and from achenes, indicating that their presence in the flower microenvironment is independent by the insect, and is likely to not affect flower physiology. In the absence of previous assessments, identification at species level appeared to be fundamental in order to conclusively establish whether these isolates are taxonomically homogeneous, hence, to be possibly regarded as specialized gall associates, or rather occur as unrelated saprophytes.

\section{Results}

\subsection{Cladosporium Isolates}

As discussed above, Cladosporium strains were quite frequently isolated from flower galls, their inquiline insects and normal flowers collected on several Lamiaceae species examined in our investigation. Forty strains from the resulting collection were selected to be examined in this study (Table 2). The list included representatives from all the sampled plant species, with a prevalence of isolates from galls depending on the higher number of isolations which were performed from this source.

Table 2. List of Cladosporium isolates recovered from galled and non-galled flowers of Lamiaceae which have been considered in the present study, with GenBank codes of the deposited DNA sequences.

\begin{tabular}{cccccc}
\hline Strain & Source & Location & ITS & TEF1 & ACT \\
\hline AjNa1 & Ajuga reptans-receptacle & Napoli & MK387884 & MK416088 & MK416045 \\
\hline AcAv2 & Clinopodium nepeta-achene & Averno & MK387911 & MK416115 & MK416072 \\
\hline AcAv4 & Clinopodium nepeta-larva of A. nepetae & Averno & MK387888 & MK416092 & MK416049 \\
\hline AcAv16 & Clinopodium nepeta-larva of parasitoid & Averno & MK387905 & MK416109 & MK416066 \\
\hline AcBa1 & Clinopodium nepeta-larva of A. nepetae & Napoli & MK387916 & MK416120 & MK416077 \\
\hline AcBa2 & Clinopodium nepeta-gall wall & Napoli & MK387899 & MK416103 & MK416060 \\
\hline AcBa3 & Clinopodium nepeta-gall wall & Napoli & MK387917 & MK416121 & MK416078 \\
\hline AcBa8 & Clinopodium nepeta-larva of parasitoid & Napoli & MK387906 & MK416110 & MK416067 \\
\hline AcCe1 & Clinopodium nepeta-gall wall & Caserta & MK387910 & MK416114 & MK416071 \\
\hline AcMn6 & Clinopodium nepeta-gall wall & Montenuovo & MK387914 & MK416118 & MK416075 \\
\hline AcMt5 & Clinopodium nepeta-gall wall & Matera & MK387880 & MK416084 & MK416041 \\
\hline AcMt6 & Clinopodium nepeta-larva of A. nepetae & Matera & MK387883 & MK416087 & MK416044 \\
\hline AcNa1 & Clinopodium nepeta-gall wall & Astroni & MK387881 & MK416085 & MK416042 \\
\hline
\end{tabular}


Table 2. Cont.

\begin{tabular}{|c|c|c|c|c|c|}
\hline Strain & Source & Location & ITS & TEF1 & $\overline{\mathrm{ACT}}$ \\
\hline AcPp1 & Clinopodium nepeta-gall wall & Pietrapertosa & MK387900 & MK416104 & MK416061 \\
\hline AcPp2 & Clinopodium nepeta-receptacle & Pietrapertosa & MK387885 & MK416089 & MK416046 \\
\hline AcRi7 & Clinopodium nepeta-receptacle & Rivello & MK387886 & MK416090 & MK416047 \\
\hline SG8 & Clinopodium nepeta-gall wall & San Giorgio a Cremano & MK387907 & MK416111 & MK416068 \\
\hline CL1 & Clinopodium vulgare-gall wall & Rivello & MK387908 & MK416112 & MK416069 \\
\hline CL3 & Clinopodium vulgare - gall wall & Rivello & MK387898 & MK416102 & MK416059 \\
\hline CL4 & Clinopodium vulgare-achene & Rivello & MK387904 & MK416108 & MK416065 \\
\hline S1 & Clinopodium vulgare-achene & Grunau im Almtal & MK387902 & MK416106 & MK416063 \\
\hline LaPo1 & Lamiastrum sp.-receptacle & Pontone & MK387878 & MK416082 & MK416039 \\
\hline LaNa1 & Lamium album-receptacle & Napoli & MK387903 & MK416107 & MK416064 \\
\hline LaVe1 & Lamium bifidum-receptacle & Ottaviano & MK387879 & MK416083 & MK416040 \\
\hline $\mathrm{LaPo} 2$ & Lamium purpureum-receptacle & Portici & MK387877 & MK416081 & MK416038 \\
\hline MfCa2 & Micromeria fruticulosa-gall wall & Capri & MK387882 & MK416086 & MK416043 \\
\hline MgPo1 & Micromeria graeca-receptacle & Pontone & MK387890 & MK416094 & MK416051 \\
\hline MgLu1 & Micromeria graeca-ovary & Lucrino & MK387918 & MK416122 & MK416079 \\
\hline MgLu2 & Micromeria graeca-receptacle & Lucrino & MK387901 & MK416105 & MK416062 \\
\hline MgVi1 & Micromeria graeca-gall wall & Vivara & MK387893 & MK416097 & MK416054 \\
\hline $\mathrm{MgVi2}$ & Micromeria graeca-larva of Asphondylia sp. & Vivara & MK387887 & MK416091 & MK416048 \\
\hline MgVi3 & Micromeria graeca-receptacle & Vivara & MK387892 & MK416096 & MK416053 \\
\hline Nc/f17 & Nepeta cataria-receptacle & Konopnica & MK387896 & MK416100 & MK416057 \\
\hline SpCa1 & Salvia sp.-receptacle & Capri & MK387891 & MK416095 & MK416052 \\
\hline ThSC1 & Thymus sp.-receptacle & Monte Santa Croce & MK387909 & MK416113 & MK416070 \\
\hline Th/S345 & Thymus vulgaris-achene & Fajsławice & MK387889 & MK416093 & MK416050 \\
\hline $\mathrm{Th} / \lg / 2015$ & Thymus vulgaris—gall wall & Fajsławice & MK387912 & MK416116 & MK416073 \\
\hline $\mathrm{Th} / \lg / 2031$ & Thymus vulgaris_-gall wall & Fajsławice & MK387897 & MK416101 & MK416058 \\
\hline $\mathrm{Th} / \lg / 2334$ & Thymus vulgaris-gall wall & Fajsławice & MK387894 & MK416098 & MK416055 \\
\hline Th/k/258 & Thymus vulgaris-receptacle & Fajsławice & MK387895 & MK416099 & MK416056 \\
\hline
\end{tabular}

\subsection{Phylogenetic Analysis}

Considering that recent work and revisions on the taxonomy of Cladosporium agree on the insufficient reliability of morphological characters for a correct species ascription $[1,8,10]$, the selected isolates were directly processed for DNA extraction and sequencing of ITS, TEF1 and ACT regions. All the obtained DNA sequences listed in Table 2 have been deposited in GenBank, to be available for further taxonomic assessments.

Identification based on DNA sequencing and BLAST searches in GenBank showed that four strains could be ascribed to $C$. ramotenellum and three to $C$. allicinum, which are widespread saprobes within the C. herbarum s.c. [1]. However, the majority of the collected strains (33) were found to belong in the C. cladosporioides s.c., and were further analyzed for assessing their phylogenetic relationships with all the members of this taxonomic group. Overall, the phylogenetic analysis included 141 strains and was based on a nucleotide set of $1164 \mathrm{bp}$ (536 bp for ITS, $373 \mathrm{bp}$ for TEF1, and $255 \mathrm{bp}$ for ACT).

The phylogram obtained through maximum likelihood (ML) analysis (Figure 1) shows that two strains from gall walls of Asphondylia nepetae can be respectively ascribed to C. delicatulum and C. perangustum, both known as saprobic and widely distributed species, while the remaining are grouped in four highlighted clades of the tree (A-D). The 16 isolates in group A are phylogenetically closely related to C. pseudocladosporioides (ML bootstrap/MP bootstrap $/$ posterior probabilities $=92 / 88 / 1.0)$, with some exceptions. In particular, isolate $\mathrm{Cl} 3$ appears to be more closely related to C. crousii, while $\mathrm{Th} / \mathrm{K} / 258$ and $\mathrm{Th} / \mathrm{lg} / 2334$, 
two Polish isolates from Thymus vulgaris, form an independent clade (ML bootstrap/MP bootstrap $/$ posterior probabilities $=87 / 87 / 1.0)$. The nine isolates in group B are phylogenetically closely related to $C$. cladosporioides (ML bootstrap/MP bootstrap/posterior probabilities $=96 / 82 / 1.0$ ), with a certain degree of variation which is inferable from their distribution in several subclades. The two isolates in group C, collected in Campania from Micromeria graeca, form an independent clade in proximity to C. xylophilum (ML bootstrap/MP bootstrap/posterior probabilities =100/100/1.0). Finally, the four isolates in group D result to belong to the same clade as C. europaeum (ML bootstrap/MP bootstrap/posterior probabilities $=100 / 100 / 1.0$ ).

\subsection{Species Delimitation Assay}

These four different groupings were separately analyzed along with the reference strains of the most closely related species by means of the automatic barcode gap discovery (ABGD) and general mixed Yule-coalescent (GMYC) methods for species delimitation. Results of these supplementary analyses were in agreement with one another, increasing the confidence of taxonomy assignments.

In detail, the set of strains forming group A was integrated by a reference strain for each of the six candidate species (Cladosporium sp. 3-8) which have been recently pointed out to exist within the C. pseudocladosporioides aggregate $[7,8]$. Besides the outgroup strain (C. hillianum), this overall set segregated in 13 taxa (Figure 2). The largest one is represented by 13 isolates, from both countries and miscellaneous origins, in association with the canonical reference strains of $C$. pseudocladosporioides, thereby confirming their belonging to this species sensu stricto. Moreover, an Italian isolate from Clinopodium vulgare (C13) matches with the representative of "Cladosporium sp. 5" (UTHSC DI-13-245), while two Polish isolates from T. vulgaris form an independent clade, which is close but separate from "Cladosporium sp. 7" (UTHSC DI-13-218).

Likewise, considering the variation resulting in the general phylogenetic analysis, the set of strains in group B was integrated with six additional representatives of C. cladosporioides of which sequences are available in GenBank (Figure 3). In this case, the congruent analyses based on ABGD and GMYC indicate that 9 isolates of assorted origin in our sample are differentiated in 4 groups, each including at least one reference strain of C. cladosporioides.

Finally, the species delimitation analysis carried out for group C (Figure 4) indicates, with strong support, that the two isolates from receptacles of $M$. graeca represent an independent species, close to $C$. xylophilum, while the two couples of isolates from both countries included in group D cluster together with C. europaeum, confirming their ascription to this species (Figure 5).

\subsection{Morphological Characteristics}

Isolates showing significant divergence from known species of the C. cladosporioides s.c., thereby representing candidate novel species as revealed by the above mentioned phylogenetic and species delimitation analyses, were further examined with reference to their morphological and cultural characteristics. Morphological characters were evaluated in comparison to the phylogenetically most closely related species (Table 3). For the species related to C. xylophilum, some differences were observed consisting in shorter conidiophores and ramoconidia, a lower number of hila on the secondary ramoconidia, and slower growth on all culturing media. Based on evidence gathered from phylogenetic analyses and morphological examination, these candidate species are described as follows. 


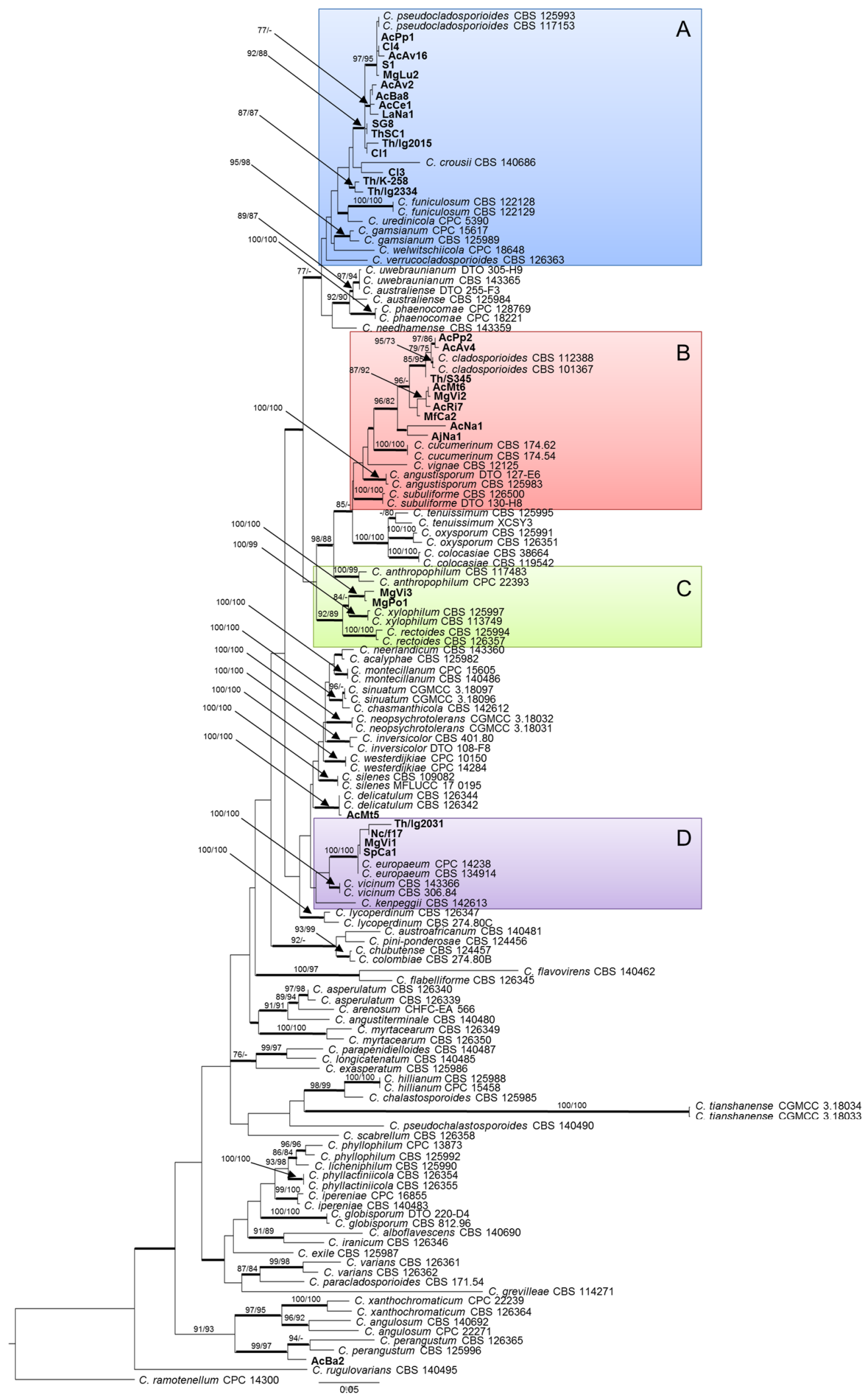

Figure 1. Phylogenetic tree based on maximum likelihood (ML) analysis of combined ITS, TEF1, and ACT sequences of 141 strains from the $C$. cladosporioides complex. Bootstrap support values $\geq 70 \%$ for ML and maximum parsimony (MP) are presented above branches as follows: ML/MP; bootstrap values $<70 \%$ are marked with ' $-'$. Branches in bold are supported by Bayesian analysis (posterior probability $>0.95$ ). C. ramotenellum $\mathrm{CPC} 14300$ was used as outgroup reference. Main clades are indicated by colored boxes A, B, C, and D. 


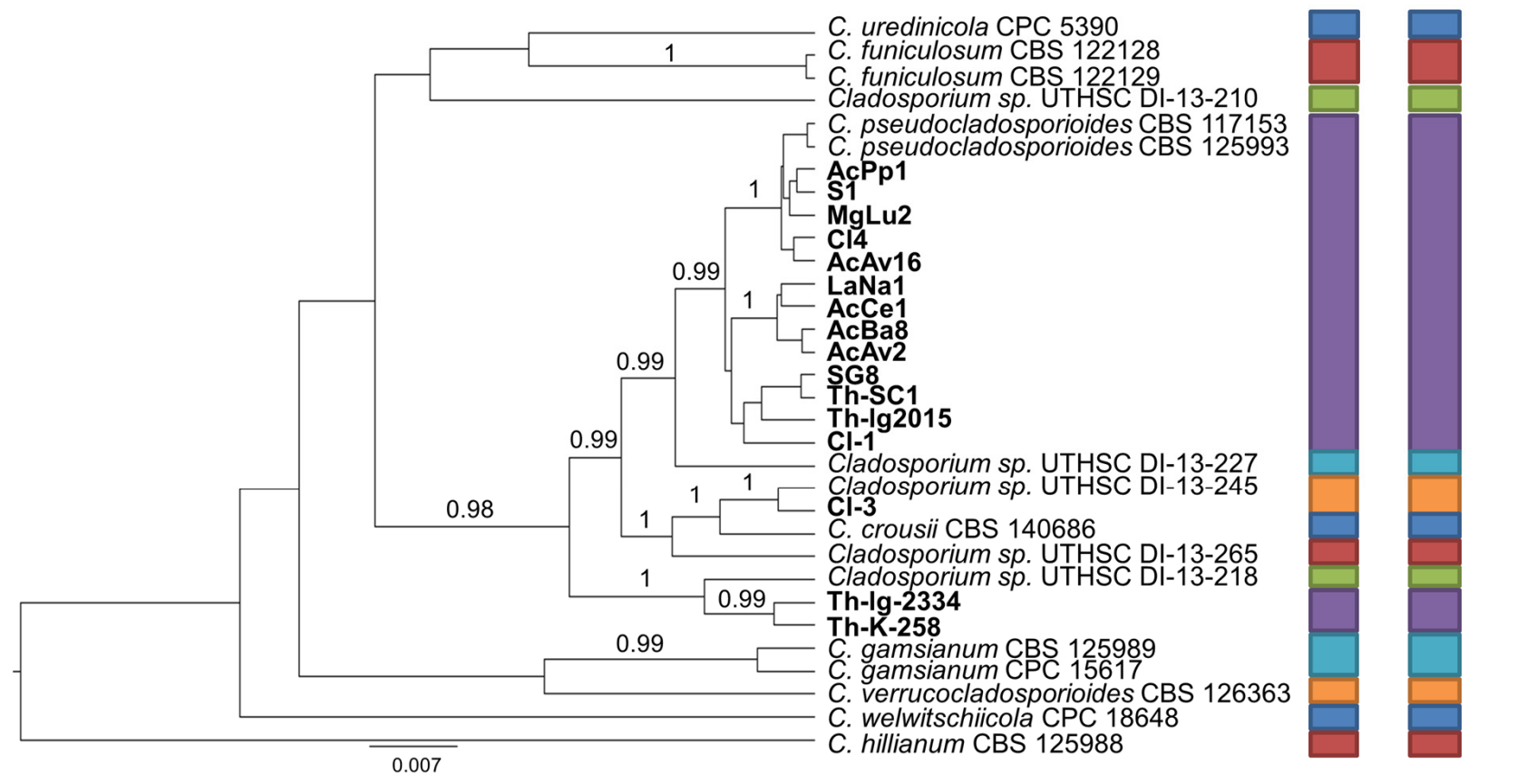

Figure 2. Ultrametric tree phylogeny of group A showing results of sequence-based species delimitation methods. The tree is the result of a Bayesian analysis performed in BEAST on the concatenated ITS, TEF1, ACT dataset. For each node, posterior probabilities (if $>0.90$ ) are presented above the branch leading to that node. Results of species delimitation analyses through automatic barcode gap discovery (ABGD) and general mixed Yule-coalescent (GMYC) methods are congruent, as visualized by colored boxes to the right.
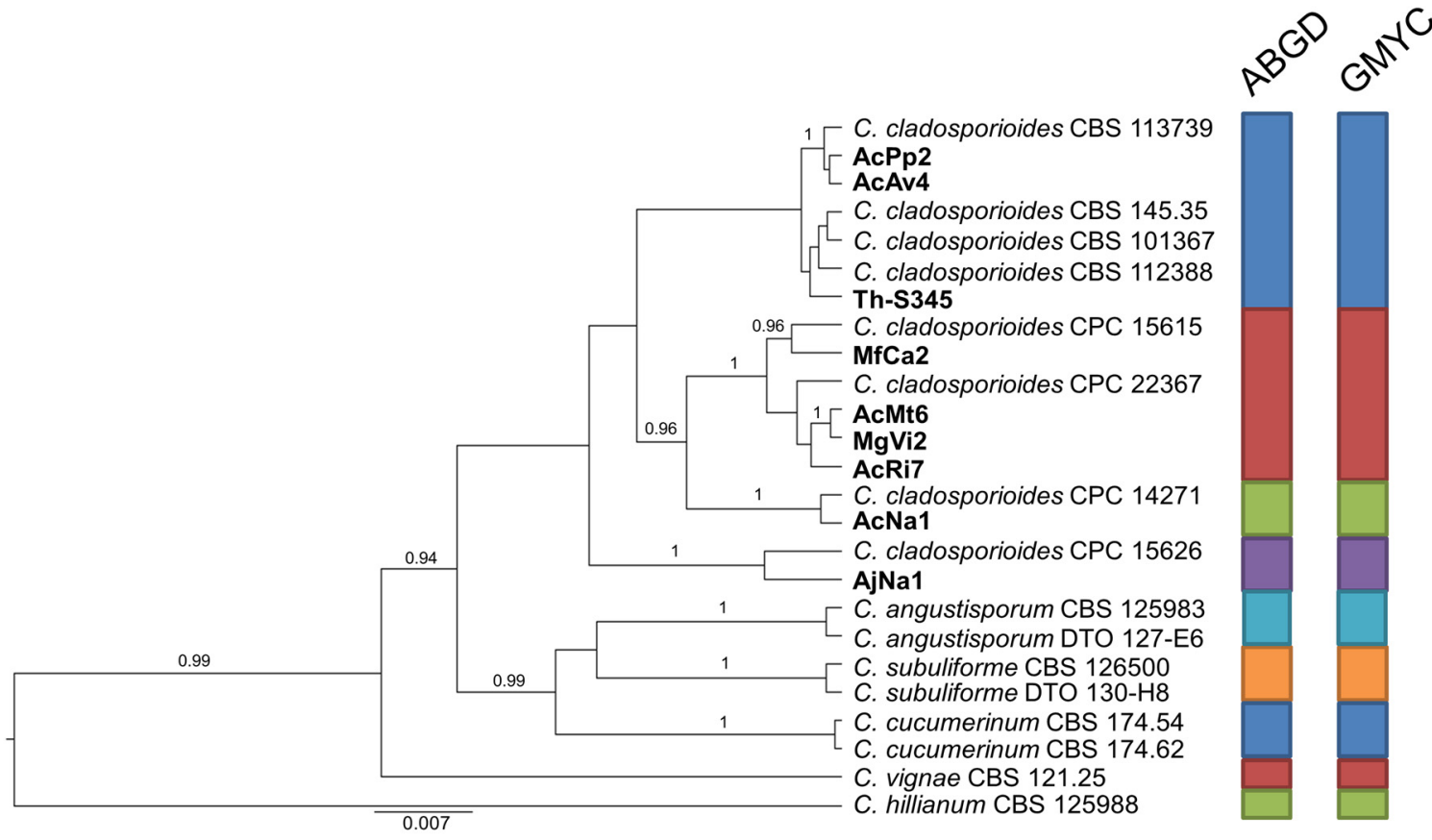

Figure 3. Ultrametric tree phylogeny of group B showing results of sequence-based species delimitation methods. The tree is the result of a Bayesian analysis performed in BEAST on the concatenated ITS, TEF1, ACT dataset. For each node, posterior probabilities (if $>0.90$ ) are presented above the branch leading to that node. Results of species delimitation analyses through ABGD and GMYC methods are congruent, as visualized by colored boxes to the right. 


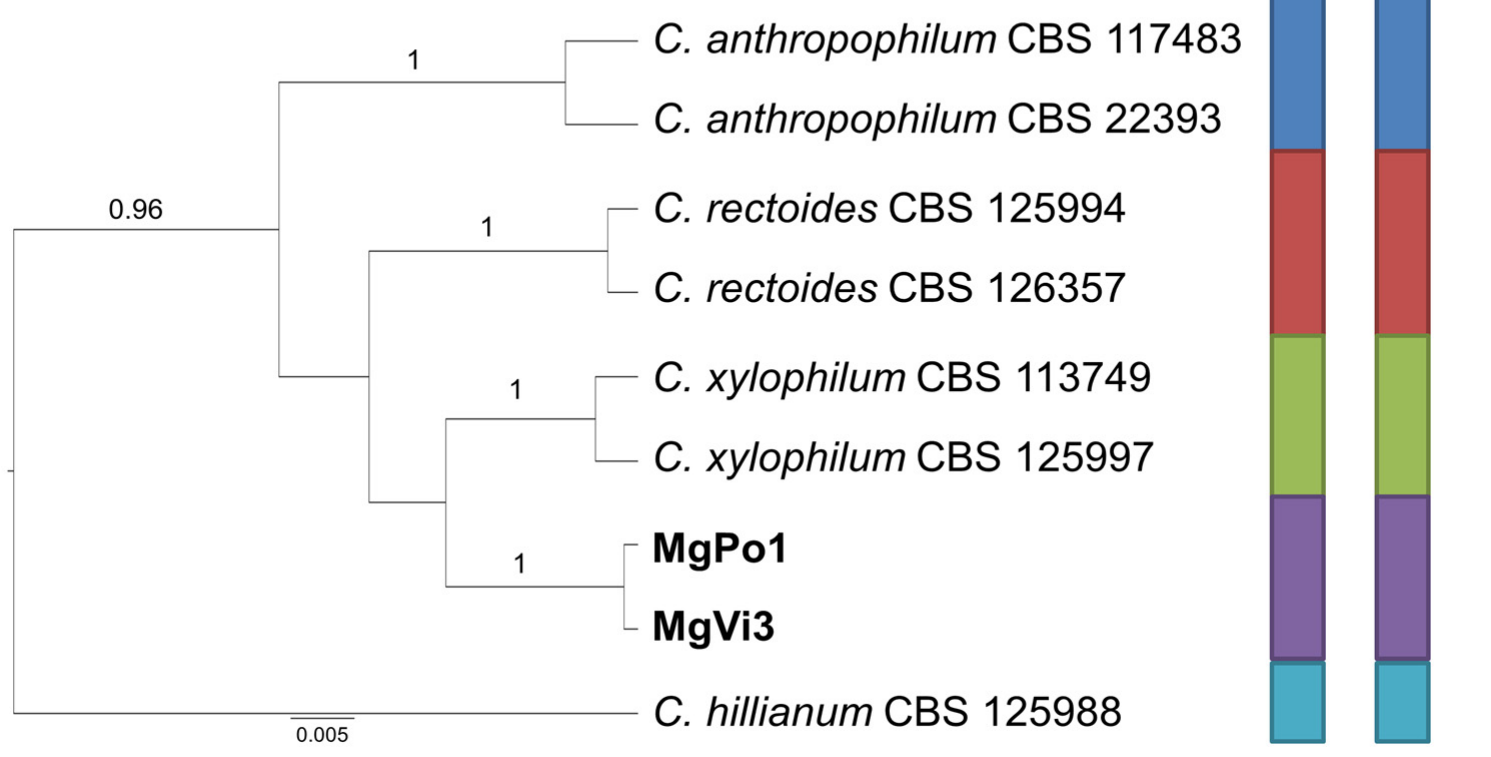

Figure 4. Ultrametric tree phylogeny of group C showing results of sequence-based species delimitation methods. The tree is the result of a Bayesian analysis performed in BEAST on the concatenated ITS, TEF1, ACT dataset. For each node, posterior probabilities (if $>0.90$ ) are presented above the branch leading to that node. Results of species delimitation analyses through ABGD and GMYC methods are congruent, as visualized by colored boxes to the right.

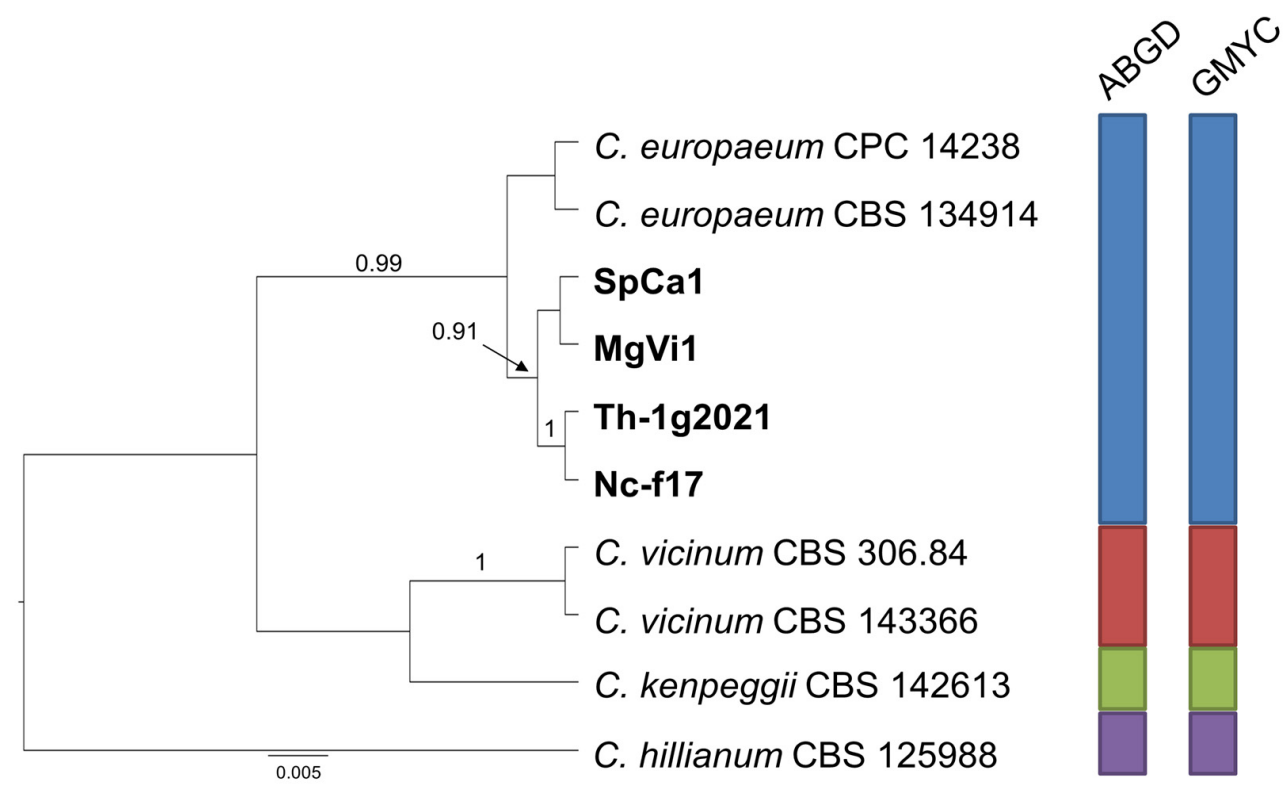

Figure 5. Ultrametric tree phylogeny of group D showing results of sequence-based species delimitation methods. The tree is the result of a Bayesian analysis performed in BEAST on the concatenated ITS, TEF1, ACT dataset. For each node, posterior probabilities (if $>0.90$ ) are presented above the branch leading to that node. Results of species delimitation analyses through ABGD and GMYC methods are congruent, as visualized by colored boxes to the right. 
Table 3. Morphological characteristics of Cladosporium species novae described in this study.

\begin{tabular}{|c|c|c|c|c|c|c|}
\hline Strains & $\begin{array}{l}\text { Conidiophores } \\
(\mu \mathrm{m})\end{array}$ & Ramoconidia ( $\mu \mathrm{m})$ & $\begin{array}{c}\text { Secondary }^{1} \\
\text { Ramoconidia }(\mu \mathrm{m})\end{array}$ & $\begin{array}{c}\text { Intercalary } \\
\text { Conidia }^{1}(\mu \mathrm{m})\end{array}$ & $\underset{(\mu \mathrm{m})}{\text { Conidia }^{1}}$ & $\begin{array}{l}\text { Colony Diameter }{ }^{2} \\
\text { after } 14 \text { Days (mm) }\end{array}$ \\
\hline $\mathrm{Th} / \lg / 2334$ & $\begin{array}{c}(22-) 70-130 \times \\
2-3.6\end{array}$ & $\begin{array}{c}12.9-36 \times 2.5-4.1 \\
0-1 \text { septate }\end{array}$ & $9.5-17.1 \times 2.4-4$ & $6.4-11 \times 2-3.5$ & $\begin{array}{l}3-5.8(-6) \times \\
(1.5-) 2-2.8\end{array}$ & $\begin{array}{c}\text { PDA: } 63 \\
\text { Malt-extract agar } \\
\text { (MEA): } 58 \\
\text { Oatmeal agar (OA): } 53\end{array}$ \\
\hline $\mathrm{Th} / \mathrm{k} / 258$ & $\begin{array}{c}(25-) 42.7-151 \times \\
2.4-5.1\end{array}$ & $\begin{array}{l}14.3-39.8 \times \\
2.4-5.2,0-1 \\
\quad \text { septate }\end{array}$ & $7.9-23.2 \times 2.6-4$ & $5.6-8.8 \times 2-3.9$ & $\begin{array}{l}3.8-5.6 \times \\
(1.5-) 2-3\end{array}$ & $\begin{array}{l}\text { PDA: } 70 \\
\text { MEA: } 53 \\
\text { OA: } 60\end{array}$ \\
\hline $\begin{array}{c}\text { Cladosporium } \\
\text { pseudocladosporioides } \\
{[3]}\end{array}$ & $15-155 \times 2-4$ & $\begin{array}{c}19-48 \times 3-4 \\
0-2(-3) \text { septate }\end{array}$ & $16.1 \times 2.9$ & $8.8 \times 2.6$ & $4.1 \times 2.1$ & $\begin{array}{l}\text { PDA: } 65-78 \\
\text { MEA: } 52-75 \\
\text { OA: } 55-73\end{array}$ \\
\hline MgPo1 & $\begin{array}{c}(28.1-) 44.4-142.5 \\
\times \\
(2.1-) 2.5-3.9(-4.5)\end{array}$ & $\begin{array}{c}10.1-20.1 \times 2.2-3.7 \\
(-4.3)\end{array}$ & \multirow{2}{*}{$\begin{array}{c}(7.1-) 8.3-14.6 \times \\
2.1-3.1, \\
2-4 \text { apical hila } \\
(5.7-) 7.4-16.6 \times \\
1.8-2.7 \\
2-4 \text { apical hila }\end{array}$} & $6.1-9.5 \times 2-2.9$ & $\begin{array}{c}(2.1-) 2.4-4.9(-5.1) \\
\times \\
(1.7-) 2.1-2.5(-2.8)\end{array}$ & $\begin{array}{l}\text { PDA: } 47 \\
\text { MEA: } 37 \\
\text { OA: } 46\end{array}$ \\
\hline $\mathrm{MgVi} 3$ & $\begin{array}{c}(57-) 68-126.5 \times \\
(1.9-) 2.4-4.2\end{array}$ & $\begin{array}{c}11.5-22.2 \times \\
2.4-3.5(-3.9)\end{array}$ & & $5.8-10.5 \times 2-3.3$ & $\begin{array}{c}(1.4-) 2.2-4.3 \times \\
(1.3-) 1.6-2.5(-2.8)\end{array}$ & $\begin{array}{l}\text { PDA: } 47 \\
\text { MEA: } 40 \\
\text { OA: } 45\end{array}$ \\
\hline $\begin{array}{l}\text { Cladosporium } \\
\text { xylophilum [3] }\end{array}$ & $\begin{array}{l}155(-190) \times \\
2-4(-5)\end{array}$ & $19-35 \times 2.5-3$ & $\begin{array}{l}14.5( \pm 5.1) \times 3.1( \pm 0.5) \\
\text { up to } 6(-9) \text { apical hila }\end{array}$ & $\begin{array}{l}7.7( \pm 2.2) \times \\
2.6( \pm 0.3)\end{array}$ & $\begin{array}{l}3.9( \pm 0.9) \times \\
2.3( \pm 0.3)\end{array}$ & $\begin{array}{l}\text { PDA: } 52-74 \\
\text { MEA: } 47-74 \\
\text { OA: } 47-58\end{array}$ \\
\hline
\end{tabular}

${ }^{1}$ Average of 50 measurements. ${ }^{2}$ Average of three replicates.

\subsection{Taxonomy}

Cladosporium polonicum Zimowska \& Król sp. nov.—MycoBank MB839011; Figure 6.
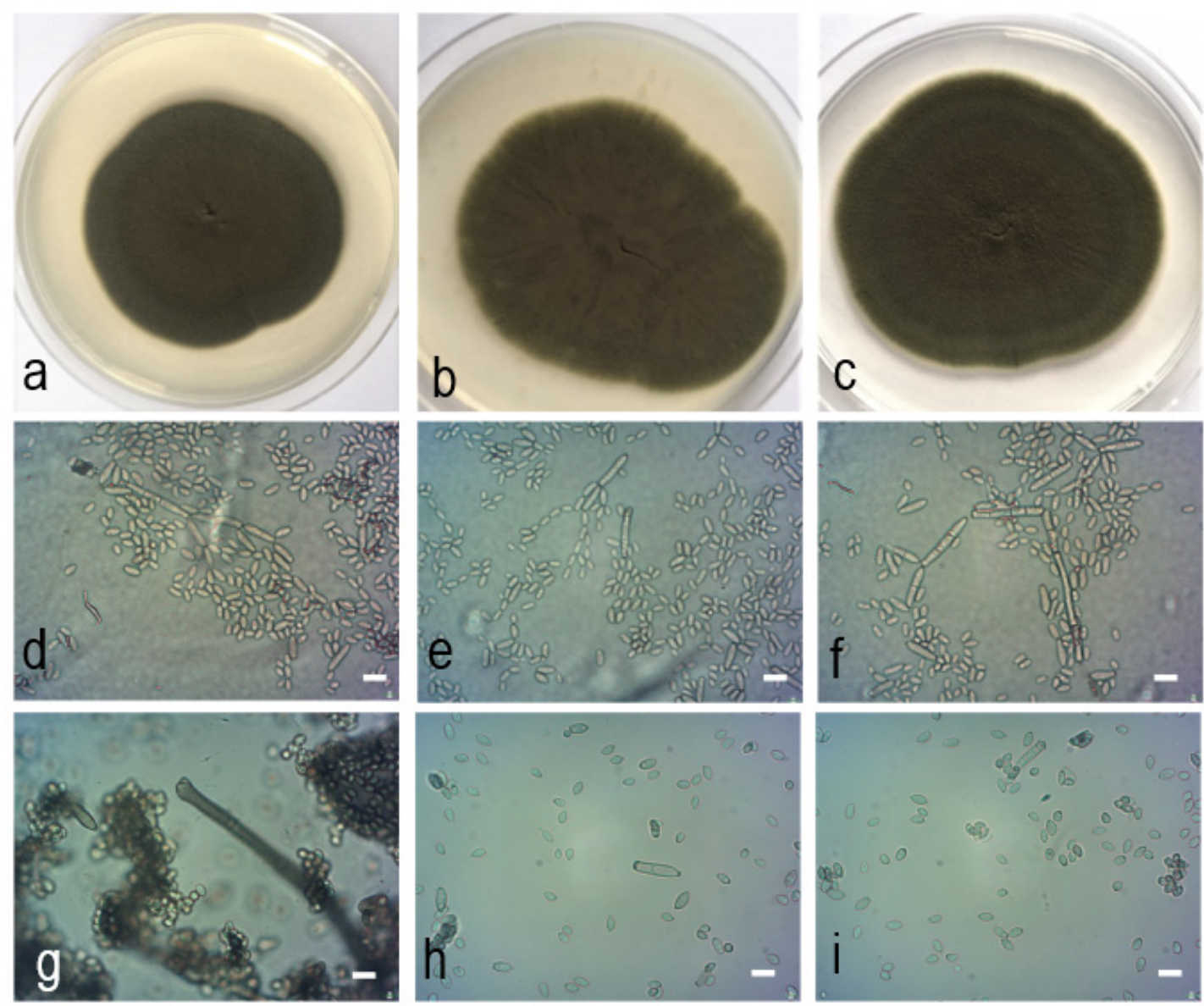

Figure 6. Cladosporium polonicum Zimowska \& Król sp. nov. (isolate Th/lg/2334, holotype). (a). Colony on PDA after $14 \mathrm{~d}$; (b). colony on OA after $14 \mathrm{~d}$; (c). colony on MEA after $14 \mathrm{~d} ;(\mathbf{d}-\mathbf{i})$. conidiophores and conidial chains; (e). tip of conidiophores and numerous conidia; (f). cylindrical-oblong, $0-1(-3)$ septate secondary ramoconidia and conidia; (g). tip of a conidiophore with several subdenticulate loci; $(\mathbf{h}-\mathbf{i})$. conidia. - Scale bars $=5 \mu \mathrm{m}$.

Similar to C. pseudocladosporioides, from which it differs in forming slightly shorter, $0-1$ septate ramoconidia and shorter secondary ramoconidia. 
Etymology: Named after the country where the representative strains were collected, Poland.

Mycelium immersed and superficial, hyphae unbranched or sparingly branched, up to $4 \mu \mathrm{m}$ wide, septate, sometimes constricted at septa, subhyaline to pale olivaceousbrown, smooth or almost so, walls sometimes slightly thickened, sometimes irregular in outline due to swellings and constrictions, cells sometimes swollen, fertile hyphae minutely verruculose, mainly at the base of conidiophores. Conidiophores macronematous, sometimes also micronematous, solitary or in small loose groups, arising terminally and laterally from hyphae, erect, straight to slightly flexuous, cylindrical-oblong, non nodulose, sometimes once geniculate-sinuous or slightly swollen at the apex, unbranched or once branched, occasionally three times, branches often only as short denticle-like lateral outgrowth just below a septum, sometimes attenuated towards the apex, 0-5 septate, sometimes slightly constricted at septa, pale to pale medium olivaceous-brown, sometimes paler towards the apex, smooth or almost so, or asperulate or finely verruculose, walls slightly thickened or unthickened: $(22-) 42.7-151 \times 2-3.6(-5.1) \mu \mathrm{m}$. Micronematous conidiophores filiform, narrower, not attenuated. Conidiogenous cells narrow, with $1-5$ loci crowded at the apex, subdenticulate, $1-1.8 \mu \mathrm{m}$ diam. Ramoconidia cylindrical-oblong, 0-1 septate pale olivaceous-brown, smooth, base broadly truncated, $2-3 \mu \mathrm{m}$ wide, unthickened or slightly thickened, sometimes slightly refractive: $12.9-39.8 \times 2.4-5.2 \mu \mathrm{m}$ (av. $20.5 \times 3.3)$. Secondary ramoconidia ellipsoid-ovoid to subcylindrical or cylindrical-oblong, $0-1(-3)$ septate, septum medium or often somewhat in the lower half, pale olivaceous to pale olivaceous-brown, smooth or almost so, sometimes slightly rough-walled, walls unthickened, with 1-4 distal hila, conspicuous, subdenticulate, somewhat thickened: 7.9-23.2 $\times 2.4-4 \mu \mathrm{m}$ (av. $12.3 \times 3.1$ ). Microcyclic conidiogenesis not observed. Conidia very numerous, catenate, in branched chains, branching in all directions. Small terminal conidia obovoid, ovoid to limoniform or ellipsoid, sometimes subglobose, apex rounded or attenuated towards apex and base, $3-5.8 \times(1.5-) 2-3 \mu \mathrm{m}$, av. $5 \times 2.2$. Intercalary conidia ovoid, limoniform to ellipsoid or subcylindrical, $0(-1)$ septate, slightly attenuated towards apex and base, with $1-4$ distal hila: $5.5-11 \times 2-3.9 \mu \mathrm{m}$, av. $7.8 \times 2.7$.

Culture characteristics: Colonies on PDA attaining 63-70 $\mathrm{mm}$ diam after 14 days at $25{ }^{\circ} \mathrm{C}$, olivaceous-grey, to grey olivaceous. Reverse leaden grey to olivaceous-black, felty-floccose, concentric ring visible in the center of colony, margin white very narrow up to $2 \mathrm{~mm}$, glabrous, regular, aerial mycelium velvety to felty, growth flat, without exudates formed, sporulation profuse. Colonies on malt-extract agar (MEA) reaching 53-58 mm, grey olivaceous, reverse iron grey, floccose, margin white very narrow up to $2 \mathrm{~mm}$, regular, glabrous, aerial mycelium velvety to felty, growth flat, without exudates, sporulation profuse, concentric ring visible in the center of colony. Colonies on oatmeal agar (OA) attaining 55-60 mm, olivaceous to grey olivaceous or olivaceous-buff, pale olivaceous-grey to greenish-grey towards margins. Reverse pale greenish-grey, leaden grey to iron grey, floccose, margin colorless up to $2 \mathrm{~mm}$, glabrous, regular, aerial mycelium floccose to felty, radial sectors in the center of colony, sporulation profuse.

Specimens examined: POLAND, Lubelskie voivodeship, Fajsławice, from gall of Asphondylia serpylli Kieffer on thyme (Thymus vulgaris L., Lamiaceae), B. Zimowska, 18 June 2016, $\mathrm{Th} / \mathrm{lg} / 2334$, holotype, preserved in a metabolically inactive state at the mycological collection of the Department of Plant Protection of the University of Life Sciences in Lublin; Konopnica, from receptacle in flower of catnip (Nepeta cataria L., Lamiaceae), B. Zimowska, 28 June 2018, $\mathrm{Th} / \mathrm{k} / 258$.

Notes: Evidence resulting in a recent study [10] indicated C. crousii to be probably conspecific with $C$. pseudocladosporioides, also with reference to the very close species descriptions. Conversely, in our analysis, the species delimitation methods support both C. crousii and C. polonicum as separate species.

Cladosporium neapolitanum Zimowska, Nicoletti \& Król sp. nov.-MycoBank MB839012; Figure 7. 

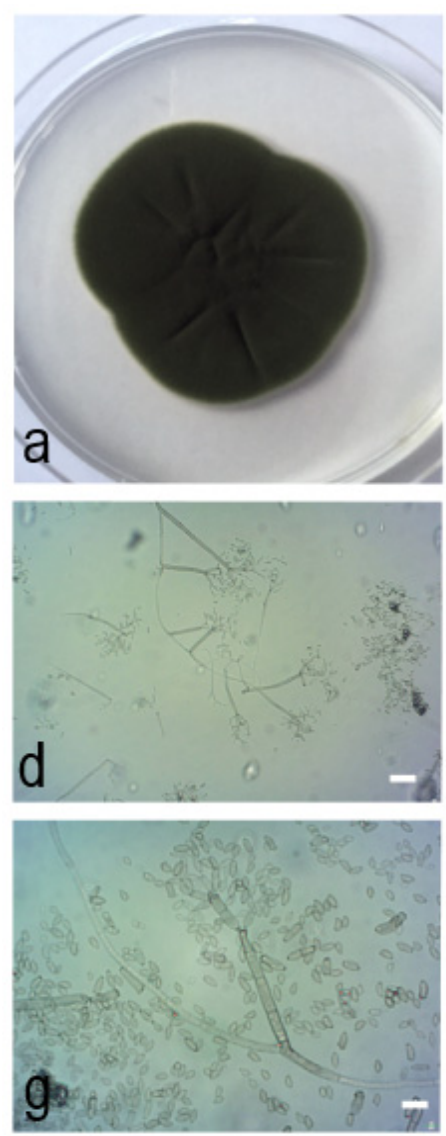
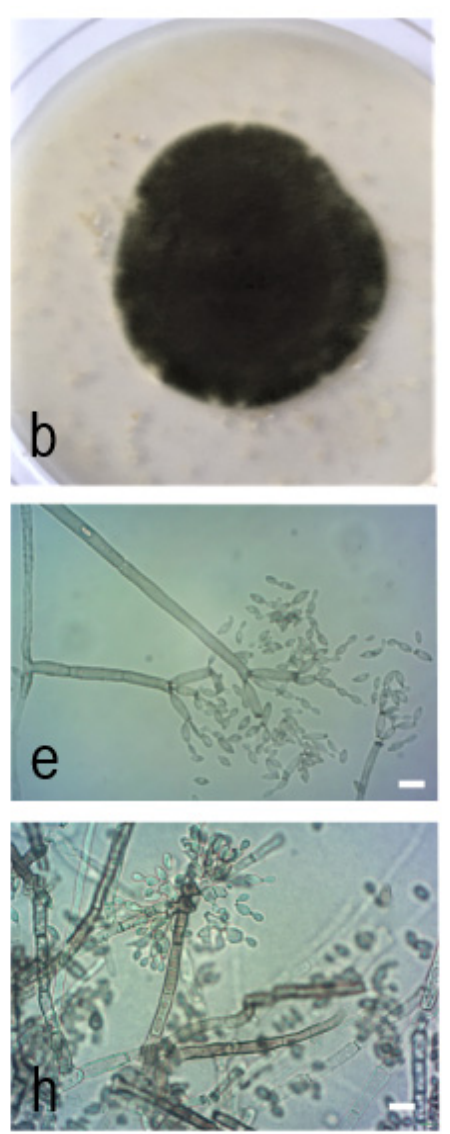
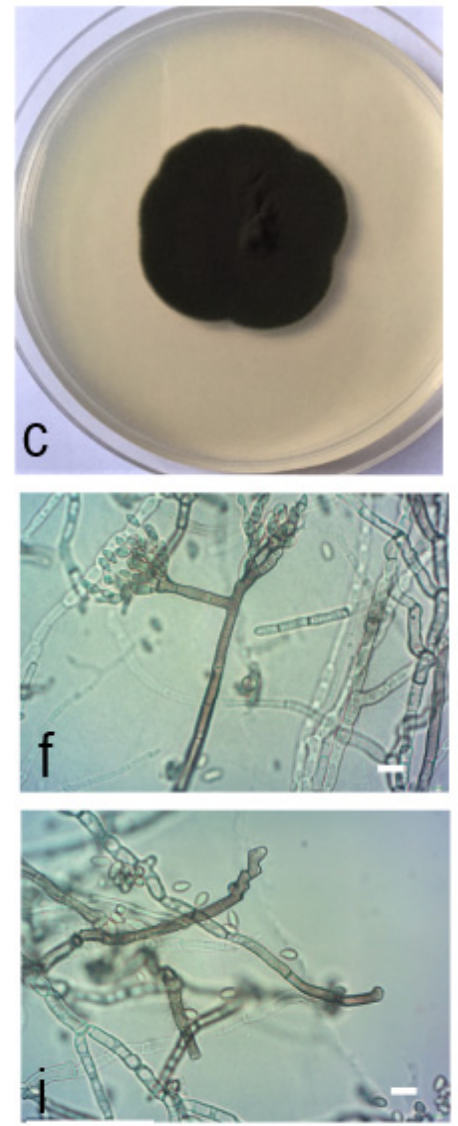

Figure 7. Cladosporium neapolitanum Zimowska, Nicoletti \& Król sp. nov. (isolate MgPo1, holotype). (a). Colony on PDA after $14 \mathrm{~d} ;(\mathbf{b})$. colony on OA after $14 \mathrm{~d}$; (c). colony on MEA after $14 \mathrm{~d} ;(\mathbf{d}-\mathbf{i})$. conidiophores and conidial chains; (d,e). macroand micronematous conidiophores growing at an angle of $45-90^{\circ} ;(\mathbf{f})$. branched condiophore; (g). one septum secondary ramoconidium with broadly truncate base and four apical hila; $(\mathbf{h}, \mathbf{i})$. peculiar conidiogenesis characterized by sympodial proliferation of conidiogenous loci.-Scale bars $=5 \mu \mathrm{m}$.

Similar to C. xylophilum, from which it differs in forming shorter conidiophores, shorter ramoconidia and secondary ramoconidia, and for a lower number of hila at the apex of secondary ramoconidia.

Etymology: Named after the city of Napoli, Italy, in which surroundings the representative strains were collected.

Mycelium immersed and superficial, hyphae unbranched or loosely branched, 1-4(5) $\mu \mathrm{m}$ wide, septate, not constricted at septa, sometimes with irregular swellings and outgrowths, subhyaline to pale or medium olivaceous-brown, smooth to asperulate, minutely verruculose or irregularly verrucose, and rough-walled, with wart-like structures on the surface, walls unthickened, occasionally swollen at the base of conidiophores. Conidiophores macro- to sometimes micronematous, solitary, arising terminally and laterally from hyphae, erect, straight to slightly flexuous, cylindrical-oblong, usually neither nodulose nor geniculate, sometimes subnodulose at the uppermost apex, occasionally geniculate-sinuous, unbranched, sometimes once branched, $0-5$ septate, sometimes slightly constricted at septa, pale to medium olivaceous-brown, smooth or almost so, sometimes somewhat irregularly rough-walled or verruculose, especially towards the base, sometimes wider at the base, or slightly toward the apex, walls slightly thickened: $(28.1-) 44.4-142.5 \times 2.4-4.2 \mu \mathrm{m}$; growth sometimes proceeding at an angle $45-90^{\circ}$. Micronematous conidiophores paler, subhyaline to pale-olivaceous-brown, smooth or almost so. Conidiogenous cells terminal and intercalary, loci crowded at the apex forming clusters of pronounced scars, $2-5$ conidiogenous loci formed at about the same level, loci often situated at lateral shoulders due to sympodial proliferation, loci 1-2 $\mu \mathrm{m}$ diam. Ramoconidia occasionally formed, cylindrical- 
oblong, $0(-1)$ septate, smooth, base broadly truncate $10.1-22.2 \times 2.2-3.7(-4.3) \mu \mathrm{m}$. Secondary ramoconidia ellipsoid to cylindrical-oblong or irregular in outline, $0-1(-3)$ septate, septum median or somewhat in the upper half, not constricted, with 2-4 distal hila, crowded at the apex or situated on small lateral prolongations, pale olivaceous to pale medium olivaceous-brown, smooth or almost so, walls unthickened or almost so, hila conspicuous, subdenticulate to denticulate, $(5.7-) 7.4-16.6 \times(1.4-) 1.8-3.1 \mu \mathrm{m}$, av. $10 \times 2.4$. Conidia numerous, catenate, in densely branched chains, branching in all directions, straight. Small terminal conidia subglobose, obovoid, sometimes globose, aseptate, slightly attenuated towards apex and base, apex broadly rounded. Small terminal conidia and intercalary conidia almost smooth to often irregularly rough-walled, loosely verruculose to verrucose, attenuated towards apex and base, $(1.7-) 2.2-4.9 \times 1.6-2.5(-2.8) \mu \mathrm{m}$, av. $3.5 \times 2$. Intercalary conidia ovoid, limoniform to ellipsoid or subcylindrical, sometimes irregular in outline, especially towards the distal end, due to numerous hila arranged in sympodial clusters of pronounced scars, $0-1$ septate, septum median, not constricted, $5.8-10.5 \times 2-3.3 \mu \mathrm{m}$, av. $7.7 \times 2.5$.

Culture characteristics: Colonies on PDA attaining $47 \mathrm{~mm}$ diameter after 14 days, pale green. Reverse iron-gray to brown-black, floccose to fluffy, margin white narrow up to $2-3 \mathrm{~mm}$, slightly irregular, aerial mycelium abundant, velvety to floccose, loose to dense, growth flat, radial sectors visible in the center of colony, without exudates, sporulation profuse. Colonies on MEA reaching 37-40 mm, pale green. Reverse olivaceous to ironblack, velvety to floccose-felty, margin white narrow up to $2-3 \mathrm{~mm}$, slightly irregular, aerial mycelium abundant, velvety to floccose, loose to dense, growth flat, radial sectors visible in the center of colony, without exudates, sporulation profuse. Colonies on OA reaching $45-46 \mathrm{~mm}$, pale green paler in the center. Reverse iron-black, velvety to floccosefelty, margin white narrow up to $2-3 \mathrm{~mm}$, slightly irregular, aerial mycelium abundant, velvety to floccose, loose, growth flat, radial sectors visible in the center of colony, without exudates, sporulation profuse.

Specimens examined: ITALY, Campania region, Pontone, from receptacle in flower of Micromeria graeca (L.) Benth. ex Rchb. (Lamiaceae), R. Nicoletti, 9 Apr. 2016, MgPo1, holotype, preserved in a metabolically inactive state at the mycological collection of the Department of Plant Protection of the University of Life Sciences in Lublin; isle of Vivara, from receptacle in flower of Micromeria graeca (L.) Benth. ex Rchb. (Lamiaceae), R. Nicoletti, 3 June 2016, MgVi3.

\section{Discussion}

Despite Cladosporium having been quite frequently reported as an associate in galls formed by Asphondyliinae on many plant species, so far, no attempts have been done to perform identification at the species level in order to ascertain whether or not these findings are to be referred to a definite species. In fact, symbiotic associations generally involve specific adaptations by the symbionts which are considered to characterize single or closely related taxa. Confirming this assumption, B. dothidea is now regarded as the fungal associate of these midges after some controversies occurred in the past which in most instances derived from nomenclatural reassessments [25,26]. This evidence obviously contrasts the hypothesis that Cladosporium may have a role in this peculiar biological association. Observations reported in the present study reinforce this conclusion, with reference to the degree of diversity which has been pointed out in the pool of Cladosporia recovered from galled and non-galled flowers of some species of Lamiaceae. In fact, our investigation carried out in two geographically distant areas demonstrated that (i) isolates of the same Cladosporium species can be recovered from both galled and non-galled flowers, and (ii) isolates from galls can be ascribed to at least seven species belonging to two species complexes.

Considering the uneven sampling with reference to both the plant species and the geographic areas, no definite association can be inferred. Within the C. herbarum s.c., the three strains of $C$. allicinum were all recovered from flower receptacles of Lamium and 
Lamiastrum spp., while the four strains of $C$. ramotenellum were found in flower receptacle of $M$. graeca and in galls of $A$. nepetae. Both these species are reported to be of worldwide occurrence in association with many heterogeneous plants [1].

Within the C. cladosporioides s.c., the species $C$. perangustum and $C$. delicatulum, both represented by single isolates from gall walls of $A$. nepetae, are known to be saprobic and widely distributed [27]. Two couples of isolates of $C$. europaeum were found on different species of Lamiaceae in Poland and Italy, which is to be taken as an indication of a more widespread occurrence in Europe of this species supporting its appropriately chosen name. In fact, it was recently separated from C. cladosporioides based on isolates from miscellaneous plant materials and indoor environments collected in Denmark, Germany, Portugal, and the Netherlands [10]; from the latter country, it has also been recovered from brown algae (Fucus sp.) [28]. With, respectively, 9 and 13 strains of assorted origin from both countries, C. cladosporioides and C. pseudocladosporioides are confirmed to be the most common representatives of this species complex. They both also show a notable degree of genetic variation, which is indicative of the possible existence of cryptic species, as predicted in previous studies and revisions $[3,4,7,8,10]$. In this respect, our phylogenetic study demonstrated correspondence of a strain from galls collected on C. vulgare to one of the candidate taxa, 'Cladosporium sp. 5', defined in the study by Sandoval-Denis et al. [7]. This strain and the two representatives of $C$. polonicum, which are also in phylogenetic proximity with C. pseudocladosporioides, might have been mistakenly ascribed to the latter species if the use of DNA sequences had been limited to a BLAST searches in the GenBank database. Hence, it is clear that in the absence of reliable morphological characters, the use of sequence-based statistical methods able to assess the significant phylogenetic distances is to be recommended in view of a correct classification, as well as to avoid the accumulation of misleading identifications of strains which have DNA sequences deposited in public repositories.

Even if displaying a certain degree of variation, many strains fitted in the cluster of C. cladosporioides. Our species delimitation analysis indicate that this grouping could be differentiated in four species, each including at least one strain from our sample and one reference strain, supporting the expectation that more new species could be separated within the currently defined C. cladosporioides. Considering that a more resolutive analysis should include most of the over 100 strains whose complete sets of sequences are available in GenBank, we decided not to try to get to more conclusive assessments in the present work, and to provisionally confirm identification of these Lamiaceae strains as C. cladosporioides.

With reference to the description of C. neapolitanum, it is interesting to consider that in their fundamental revision Bensch et al. [3] pointed out the existence of a certain degree of variation within C. xylophilum, and that the possible existence of cryptic species would have required to be ascertained based on a broader strain sample. Our finding seems to represent the first occasion meeting this expectation.

Besides emphasizing the need of a thorough revision of strains currently classified as C. cladosporioides and C. pseudocladosporioides, by the finding of two novel species our study confirms the taxonomic heterogeneity of the Cladosporium complex associated with flowers of Lamiaceae. Indeed, these plants represent a fruitful investigational ground for studying diversity of these ubiquitous fungi, also with reference to the possible contribution by endophytic strains to the biosynthesis of components of essential oils and other bioactive compounds, representing the basic property sustaining their industrial exploitation [29-32] Interestingly, two isolates of each new species were found in two ecologically homogeneous areas in Poland and in Italy. Future investigations will disclose if they should be regarded as regional entities, or rather as more widespread taxa. 


\section{Materials and Methods}

\subsection{Isolates Collection}

Cladosporium isolates considered in this study (Table 2) were recovered over 4 years (2015-2018) from several Lamiaceae species. Particularly, this sampling activity involved cropped T. vulgaris and a stand of N. cataria in Lubelskie voivodeship, south-eastern Poland, and species of Clinopodium, Micromeria, and a few additional taxa from several locations in Campania and Basilicata regions, southern Italy. A single isolate recovered from C. vulgare collected in Grunau im Almtal, Austria, was also included. Asphondylia galls were only found on Clinopodium nepeta, C. vulgare, Micromeria fruticulosa, M. graeca in Italy, and T. vulgaris in Poland, which implies that the isolates from the other species were all obtained from normal flowers. Isolation of fungal associates from gall walls and inquilines, that is midge larvae or their parasitoids, was carried out as specified in previous papers $[23,24]$. Isolations from the inner flower parts (receptacle, ovaries, or achenes developing inside the flower calyx) were carried out on potato-dextrose agar (PDA: Difco, Paris, France) amended with streptomycin sulphate $\left(200 \mathrm{mg} \mathrm{L}^{-1}\right)$, after dissecting the flowers with a sterilized scalpel in a laminar flow hood. All isolates were transferred in pure culture for taxonomic identification and storage in our in-house mycological collections.

\subsection{DNA Isolation, Amplification and Sequencing}

Selected strains were sampled from the surface of PDA cultures with a scalpel. The mycelial matter was transferred to $1.5 \mathrm{~mL}$ Eppendorf tubes for DNA extraction. DNA isolation was performed by means of a DNA easy plant and fungi isolation kit (EurX, Gdańsk, Poland), according to manufacturer's protocol. DNA concentration was estimated on 1.5\% agarose gel, compared with GeneRulerTM DNA Ladder Plus (Thermo Scientific, Waltham, MA, USA), and measured through a NanoDrop 2000 spectrophotometer (Thermo Scientific). DNA samples were diluted to a concentration of $20 \mathrm{ng} \mu \mathrm{L}^{-1}$ and stored at $-20^{\circ} \mathrm{C}$. Amplification of loci currently considered in taxonomy of Cladosporium [4] was carried out using primers ITS1 and ITS4 for the rDNA-ITS region, primers EF1-728F and EF1-986R for the translation elongation factor 1-alpha (TEF1) region, primers ACT-512F and ACT-783R for the actin gene (ACT) [33]. PCR reaction mixtures, containing $20 \mathrm{ng}$ of genomic DNA, $0.2 \mathrm{mM}$ dNTP, $0.2 \mathrm{mM}$ of each primer, $10 \times$ Taq buffer $(10 \mathrm{mM}$ Tris$\mathrm{HCl}, 1.5 \mathrm{mM} \mathrm{MgCl}_{2}$, and $50 \mathrm{mM} \mathrm{KCl}$ ), and $1 \mathrm{U}$ of Taq polymerase, were adjusted to a final volume of $25 \mu \mathrm{L}$ with sterile distilled water. PCR was conducted in a Biometra T1 thermocycler (Analytik Jena, Jena, Germany). The following reaction profile was applied: $95^{\circ} \mathrm{C}-5 \mathrm{~min}, 35$ cycles $\left(95^{\circ} \mathrm{C}-45 \mathrm{~s}, 52^{\circ} \mathrm{C}-45 \mathrm{~s}\right.$, and $\left.72^{\circ} \mathrm{C}-45 \mathrm{~s}\right)$, with final elongation at $72{ }^{\circ} \mathrm{C}-5 \mathrm{~min}$. PCR products were separated in $1.5 \%$ agarose gels containing ethidium bromide in Tris/borate/EDTA buffer, at $140 \mathrm{~V}$, for $1 \mathrm{~h}$. After checking and determining the size of the resulting PCR products, samples were submitted for sequencing to Genomed (Warsaw, Poland).

\subsection{Phylogenetic Analyses}

The obtained nucleotide sequences were blasted in GenBank for a provisional species identification. Moreover, sequences of isolates belonging to the $C$. cladosporioides s.c. were submitted to a phylogenetic analysis including GenBank sequences of one or two strains for all the described species in this s.c. (Table 1). Strain CPC 14300 of C. ramotenellum, a species belonging to the C. herbarum s.c., was used as outgroup. The combined ITS, TEF1, and ACT sequences were aligned by using Muscle [34] and manually adjusted with AliView software [35], where necessary. Congruence between the different datasets was tested through the partition homogeneity test in PAUP software version 4.0b10 [36]. Gaps were treated as missing characters. The phylogenetic analyses were carried out in conformity with recent protocols [7,37]. The best nucleotide substitution model (generalized time-reversible model with gamma distribution and a portion of invariable sites $(G T R+G+I)$ for the three independent data sets) was estimated using jModelTest version 2.3 [38] following the Akaike criterion. Phylogenetic analyses of the concatenated sequence data for maximum 
likelihood (ML) were performed by using RAxML software version 8.2.12 [39] with the GTR+G+I model of nucleotide substitution and 1000 bootstrap replications. Concatenated sequences were also analyzed for maximum parsimony (MP) by using PAUP, under the heuristic search parameters with tree bisection reconnection branch swapping, 100 random sequence additions, maxtrees set up to 1000, and 1000 bootstrap. Bayesian analyses were done with a Markov chain Monte Carlo (MCMC) coalescent approach implemented in BEAST 2 [40], using the uncorrelated lognormal relaxed clock, the GTR+G+I model, and a coalescent tree prior. Bayesian MCMC was run for 50 million generations, and trees and parameters were sampled every 1000 generations. The resulting $\log$ files were entered in Tracer v1.6.0 to check trace plots for convergence and effective sample size (ESS). Burn-in was adjusted to achieve ESS values of $\geq 200$ for the majority of the sampled parameters. While removing a portion of each run as burn-in, log files and trees files were combined in LogCombiner. TreeAnnotator was used to generate consensus trees with $25 \%$ burn-in and to infer the maximum clade credibility tree, with the highest product of individual clade posterior probabilities. Phylogenetic trees were drawn by using FigTree software (tree.bio.ed.ac.uk/software/figtree/) (accessed on 10 December 2020). Both the alignments and the trees were deposited in Zenodo.

\subsection{DNA-Based Species Delimitation}

Four clades of the tree resulting from the general phylogenetic analysis were selected for DNA-based species delimitation analysis, in order to provide taxonomic assignment for our isolates. We explored two different delimitation methods, the automatic barcode gap discovery (ABGD) [41] and the general mixed Yule-coalescent (GMYC) model [42]. These methods are among the most popular approaches for species delimitation based on sequence data and are frequently used in studies on fungal diversity [43-45]. When several methods for species delimitation offer congruent estimates of species diversity, the confidence of taxonomy assignment for a given dataset increases [44]. The ABGD method was tested through a web interface (abgd web, bioinfo.mnhn.fr/abi/public/ abgd/abgdweb.html) (accessed on 15 December 2020). Before analysis, the model criteria were set as follows: variability $(\mathrm{P})$ between 0.001 (Pmin) and 0.1 (Pmax), minimum gap width $(X)$ of 0.1 , Kimura-2-parameters and 50 screening steps. To perform the GMYC delimitation method, an ultrametric tree was constructed in BEAST 2, as described above. After removing $25 \%$ of the trees as burn-in, the remaining trees were used to generate a single summarized tree in TreeAnnotator v.2.0.2 (part of the BEAST v.2.0.2 package) as an input file for GMYC analyses. The GMYC analyses with a single threshold model were performed in $\mathrm{R}$ (R Development Core Team, www.R-project.org) (accessed on 15 December 2020) under the "splits" package using the "gmyc" function (R-Forge, r-forge.r-project.org/ projects/splits/) (accessed on 15 December 2020).

\subsection{Morphological Observations}

Morphological observations were carried out for strains representing candidate novel species. For the assessment of cultural characteristics, the isolates were grown on PDA, oatmeal agar (OA), and malt-extract agar (MEA, Difco), for 14 days at $24^{\circ} \mathrm{C}$ in the dark. The colony right and reverse colours were rated according to the charts set up by Rayner [46]. Micromorphological observations were made from colonies grown for 7 days at $24{ }^{\circ} \mathrm{C}$ on synthetic nutrient-poor agar (SNA). Squares of transparent adhesive tape (Dalpo, Poznań, Poland) were placed on the sporulating areas at the colony margin. Observations were carried out under a BA 210 microscope (Motic, Xiamen, China), and images were taken through a 1 MP Motic camera and Scopelmage 9.0 software (Bioimager, Vaughan, Canada). From each isolate, minimum, maximum and mean values were measured for a set of relevant characters considered in taxonomy of this fungal genus [3]. Descriptions followed terminology used in Bensch et al. [1]. 
Author Contributions: Conceptualization, B.Z. and R.N.; methodology, B.Z., A.B., E.D.K., and A.F.; data curation, A.B. and E.D.K.; writing-original draft preparation, B.Z. and R.N.; writing-review and editing, B.Z., K.B., and R.N.; supervision, K.B. All authors have read and agreed to the published version of the manuscript.

Funding: This research received no external funding.

Institutional Review Board Statement: Not applicable.

Informed Consent Statement: Not applicable.

Data Availability Statement: No new data were created or analyzed in this study. Data sharing is not applicable to this article.

Acknowledgments: We gratefully acknowledge contribution by G. Viggiani (University of Naples 'Federico II', Italy) in stimulating our attention and interest in the peculiar association between fungi and gall midges, and in providing some samples of Clinopodium spp. to be used for isolations. We are also thankful to J. Houbraken (Westerdijk Fungal Biodiversity Institute, Utrecht, The Netherlands) for his authoritative advising, and C. Alvino for allowing us to access the Vivara Isle Nature Reserve for plant sampling.

Conflicts of Interest: The authors declare no conflict of interest.

\section{References}

1. Bensch, K.; Groenewald, J.Z.; Braun, U.; Dijksterhuis, J.; de Jesús Yáñez-Morales, M.; Crous, P.W. Common but different: The expanding realm of Cladosporium. Stud. Mycol. 2015, 82, 23-74. [CrossRef]

2. Schubert, K. Morphotaxonomic Revision of Foliicolous Cladosporium Species (Hyphomycetes). Ph.D. Thesis, MathematischNaturwissenschaftlich-Technischen Fakultät, Martin-Luther-University Halle, Wittenberg, Germany, 2005.

3. Bensch, K.; Braun, U.; Groenewald, J.Z.; Crous, P.W. The genus Cladosporium. Stud. Mycol. 2012, 72, 1-401. [CrossRef]

4. Marin-Felix, Y.; Groenewald, J.Z.; Cai, L.; Chen, Q.; Marincowitz, S.; Barnes, I.; Bensch, K.; Braun, U.; Camporesi, E.; Damm, U.; et al. Genera of phytopathogenic fungi: GOPHY 1. Stud. Mycol. 2017, 86, 99-216. [CrossRef] [PubMed]

5. Rosado, A.W.C.; Custódio, F.A.; Pinho, D.B.; Ferreira, A.P.S.; Pereira, O.L. Cladosporium species associated with disease symptoms on Passiflora edulis and other crops in Brazil, with descriptions of two new species. Phytotaxa 2019, 409, 239-260. [CrossRef]

6. Velázquez-Jiménez, Y.; Hernández-Castro, R.; Romero-Romero, L.; Salas-Garrido, C.G.; Martínez-Chavarría, L.C. Feline phaeohyphomycotic cerebellitis caused by Cladosporium cladosporioides-complex: Case report and review of literature. J. Comp. Pathol. 2019, 170, 78-85. [CrossRef] [PubMed]

7. Sandoval-Denis, M.; Sutton, D.A.; Martin-Vicente, A.; Cano-Lira, J.F.; Wiederhold, N.; Guarro, J.; Gené, J. Cladosporium species recovered from clinical samples in the United States. J. Clin. Microbiol. 2015, 53, 2990-3000. [CrossRef] [PubMed]

8. Sandoval-Denis, M.; Gené, J.; Sutton, D.A.; Wiederhold, N.; Cano-Lira, J.F.; Guarro, J. New species of Cladosporium associated with human and animal infections. Persoonia 2016, 36, 281. [CrossRef]

9. Zhou, Y.B.; Chen, P.; Sun, T.T.; Wang, X.J.; Li, D.M. Acne-like subcutaneous phaeohyphomycosis caused by Cladosporium cladosporioides: A rare case report and review of published literatures. Mycopathologia 2016, 181, 567-573. [CrossRef]

10. Bensch, K.; Groenewald, J.Z.; Meijer, M.; Dijksterhuis, J.; Jurjević, Ž.; Andersen, B.; Houbraken, J.; Crous, P.W.; Samson, R.A. Cladosporium species in indoor environments. Stud. Mycol. 2018, 89, 177-301. [CrossRef] [PubMed]

11. Ma, R.; Chen, Q.; Fan, Y.L.; Wang, Q.; Chen, S.F.; Liu, X.Z.; Cai, L.; Yao, B. Six new soil-inhabiting Cladosporium species from plateaus in China. Mycologia 2017, 109, 244-260. [CrossRef]

12. Crous, P.W.; Wingfield, M.J.; Burgess, T.I.; Hardy, G.E.St.J.; Gené, J.; Guarro, J.; Baseia, I.G.; García, D.; Gusmão, L.F.P.; SouzaMotta, C.M.; et al. Fungal planet description sheets: 716-784. Persoonia 2018, 40, 240-393. [CrossRef] [PubMed]

13. Tibpromma, S.; Hyde, K.D.; Bhat, J.D.; Mortimer, P.E.; Xu, J.; Promputtha, I.; Doilom, M.; Yang, J.-B.; Tang, A.M.C.; Karunarathna, S.C. Identification of endophytic fungi from leaves of Pandanaceae based on their morphotypes and DNA sequence data from southern Thailand. MycoKeys 2018, 33, 25-67. [CrossRef] [PubMed]

14. Iturrieta-González, I.; García, D.; Gené, J. Novel species of Cladosporium from environmental sources in Spain. MycoKeys 2021, 77, 1-25. [CrossRef]

15. Vega, F.E.; Goettel, M.S.; Blackwell, M.; Chandler, D.; Jackson, M.A.; Keller, S.; Koike, M.; Maniania, N.K.; Monzón, A.; Ownley, B.H.; et al. Fungal entomopathogens: New insights on their ecology. Fungal Ecol. 2009, 2, 149-159. [CrossRef]

16. De Silva, N.I.; Brooks, S.; Lumyong, S.; Hyde, K.D. Use of endophytes as biocontrol agents. Fungal Biol. Rev. 2019, 33, 133-148. [CrossRef]

17. Baccarini, P. Sopra un curioso cecidio della Capparis spinosa L. Malpighia 1893, 7, 405-414.

18. Docters van Leeuwen, W.M. Ueber eine galle auf Symploccus fasiculata Zoll., verursacht durch eine gallmucke: Asphondylia bursaria Felt, die mit einem fungus zusammen lebt. Marcellia 1929, 25, 61-66.

19. Adair, R.J.; Burgess, T.; Serdani, M.; Barber, P. Fungal associations in Asphondylia (Diptera: Cecidomyiidae) galls from Australia and South Africa: Implications for biological control of invasive acacias. Fungal Ecol. 2009, 2, 121-134. [CrossRef] 
20. Lebel, T.; Peele, C.; Veenstra, A. Fungi associated with Asphondylia (Diptera: Cecidomyiidae) galls on Sarcocornia quinqueflora and Tecticornia arbuscula (Chenopodiaceae). Fungal Divers. 2012, 55, 143-154. [CrossRef]

21. Kobune, S.; Kajimura, H.; Masuya, H.; Kubono, T. Symbiotic fungal flora in leaf galls induced by Illiciomyia yukawai (Diptera: Cecidomyiidae) and in its mycangia. Microbial Ecol. 2012, 63, 619-627. [CrossRef] [PubMed]

22. Borkent, A.; Bissett, J. Gall midges (Diptera: Cecidomyiidae) are vectors for their fungal symbionts. Symbiosis 1985, 1, 185-194.

23. Zimowska, B.; Viggiani, G.; Nicoletti, R.; Furmanczyk, A.; Becchimanzi, A.; Kot, I. First report of the gall midge Asphondylia serpylli on thyme (Thymus vulgaris), and identification of the associated fungal symbiont. Ann. Appl. Biol. 2017, 171, 89-94. [CrossRef]

24. Bernardo, U.; Nugnes, F.; Gualtieri, L.; Nicoletti, R.; Varricchio, P.; Sasso, R.; Viggiani, G. A new gall midge species of Asphondylia (Diptera: Cecidomyiidae) inducing flower galls on Clinopodium nepeta (Lamiaceae) from Europe, its phenology, and associated fungi. Environ. Entomol. 2018, 47, 609-622. [CrossRef]

25. Zimowska, B.; Okoń, S.; Becchimanzi, A.; Krol, E.D.; Nicoletti, R. Phylogenetic characterization of Botryosphaeria strains associated with Asphondylia galls on species of Lamiaceae. Diversity 2020, 12, 41. [CrossRef]

26. Park, I.; Sanogo, S.; Hanson, S.F.; Thompson, D.C. Molecular identification of Botryosphaeria dothidea as a fungal associate of the gall midge Asphondylia prosopidis on mesquite in the United States. BioControl 2019, 64, 209-219. [CrossRef]

27. Bensch, K.; Groenewald, J.Z.; Dijksterhuis, J.; Starink-Willemse, M.; Andersen, B.; Summerell, B.A. Species and ecological diversity within the Cladosporium cladosporioides complex (Davidiellaceae, Capnodiales). Stud. Mycol. 2010, 67, 1-94. [CrossRef] [PubMed]

28. Patyshakuliyeva, A.; Falkoski, D.L.; Wiebenga, A.; Timmermans, K.; de Vries, R.P. Macroalgae derived fungi have high abilities to degrade algal polymers. Microorganisms 2020, 8, 52. [CrossRef]

29. Wang, X.; Radwan, M.M.; Taráwneh, A.H.; Gao, J.; Wedge, D.E.; Rosa, L.H.; Cutler, H.G.; Cutler, S.J. Antifungal activity against plant pathogens of metabolites from the endophytic fungus Cladosporium cladosporioides. J. Agric. Food Chem. 2013, 61, 4551-4555. [CrossRef]

30. Nicoletti, R.; Fiorentino, A. Plant bioactive metabolites and drugs produced by endophytic fungi of Spermatophyta. Agriculture 2015, 5, 918-970. [CrossRef]

31. Katoch, M.; Pull, S. Endophytic fungi associated with Monarda citriodora, an aromatic and medicinal plant and their biocontrol potential. Pharm. Biol. 2017, 55, 1528-1535. [CrossRef]

32. Karpiński, T.M. Essential oils of Lamiaceae family plants as antifungals. Biomolecules 2020, 10, 103. [CrossRef] [PubMed]

33. Carbone, I.; Kohn, L.M. A method for designing primer sets for speciation studies in filamentous ascomycetes. Mycologia 1999, 91, 553-556. [CrossRef]

34. Edgar, R.C. MUSCLE: Multiple sequence alignment with high accuracy and high throughput. Nucleic Acids Res. 2004, 32, 1792-1797. [CrossRef]

35. Larsson, A. AliView: A fast and lightweight alignment viewer and editor for large datasets. Bioinformatics 2014, 30, 3276-3278. [CrossRef]

36. Wilgenbusch, J.C.; Swofford, D. Inferring evolutionary trees with PAUP*. Curr. Prot. Bioinform. 2003, 00, 6.4.1-6.4.28. [CrossRef] [PubMed]

37. Dissanayake, A.J.; Bhunjun, C.S.; Maharachchikumbura, S.S.N.; Liu, J.K. Applied aspects of methods to infer phylogenetic relationships amongst fungi. Mycosphere 2020, 11, 2652-2676. [CrossRef]

38. Darriba, D.; Taboada, G.L.; Doallo, R.; Posada, D.J. jModelTest 2: More models, new heuristics and high-performance computing. Nat. Methods 2012, 9, 772. [CrossRef]

39. Stamatakis, A. RAxML-VI-HPC: Maximum likelihood-based phylogenetic analyses with thousands of taxa and mixed models. Bioinformatics 2006, 22, 2688-2690. [CrossRef]

40. Bouckaert, R.; Heled, J.; Kühnert, D.; Vaughan, T.; Wu, C.-H.; Xie, D.; Suchard, M.A.; Rambaut, A.; Drummond, A.J. BEAST 2: A software platform for Bayesian evolutionary analysis. PLoS Comput. Biol. 2014, 10, e1003537. [CrossRef] [PubMed]

41. Puillandre, N.; Lambert, A.; Brouillet, S.; Achaz, G. ABGD, Automatic Barcode Gap Discovery for primary species delimitation. Mol. Ecol. 2012, 21, 1864-1877. [CrossRef] [PubMed]

42. Pons, J.; Barraclough, T.G.; Gomez-Zurita, J.; Cardoso, A.; Duran, D.P.; Hazell, S.; Kamoun, S.; Sumlin, W.D.; Vogler, A.P. Sequence-based species delimitation for the DNA taxonomy of undescribed insects. Syst. Biol. 2006, 55, 595-609. [CrossRef] [PubMed]

43. Bustamante, D.E.; Oliva, M.; Leiva, S.; Mendoza, J.E.; Bobadilla, L.; Angulo, G.; Calderon, M.S. Phylogeny and species delimitations in the entomopathogenic genus Beauveria (Hypocreales, Ascomycota), including the description of B. peruviensis sp. nov. MycoKeys 2019, 58, 47. [CrossRef] [PubMed]

44. Haelewaters, D.; De Kesel, A.; Pfister, D.H. Integrative taxonomy reveals hidden species within a common fungal parasite of ladybirds. Sci. Rep. 2018, 8, 15966. [CrossRef] [PubMed]

45. Parnmen, S.; Rangsiruji, A.; Mongkolsuk, P.; Boonpragob, K.; Nutakki, A.; Lumbsch, H.T. Using phylogenetic and coalescent methods to understand the species diversity in the Cladia aggregata complex (Ascomycota, Lecanorales). PLoS ONE 2012, 7 , e52245. [CrossRef]

46. Rayner, R.W. A Mycological Colour Chart; Commonwealth Mycological Institute; British Mycological Society: Kew, UK, 1970; 34p. 